\title{
ECAR-4322 BASELINE CHARACTERIZATION DATABASE VERIFICATION REPORT - 2114 BILLET A20570
}

\section{December 2019}

David T Rohrbaugh

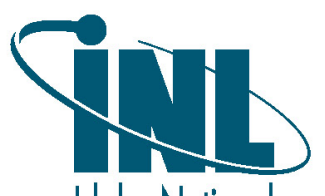

Idaho National

Laboratory 


\section{DISCLAIMER}

This information was prepared as an account of work sponsored by an agency of the U.S. Government. Neither the U.S. Government nor any agency thereof, nor any of their employees, makes any warranty, expressed or implied, or assumes any legal liability or responsibility for the accuracy, completeness, or usefulness, of any information, apparatus, product, or process disclosed, or represents that its use would not infringe privately owned rights. References herein to any specific commercial product, process, or service by trade name, trade mark, manufacturer, or otherwise, does not necessarily constitute or imply its endorsement, recommendation, or favoring by the U.S. Government or any agency thereof. The views and opinions of authors expressed herein do not necessarily state or reflect those of the U.S. Government or any agency thereof. 


\title{
ECAR-4322 BASELINE CHARACTERIZATION DATABASE VERIFICATION REPORT - 2114 BILLET A20570
}

\author{
David T Rohrbaugh
}

December 2019

\begin{abstract}
Idaho National Laboratory Idaho Falls, Idaho 83415
\end{abstract}

http://www.inl.gov

Prepared for the U.S. Department of Energy Under DOE Idaho Operations Office

Contract DE-AC07-05ID14517 
Rev. 08

Title: $\quad$ Baseline Characterization Database Verification Report - 2114 Billet A20570

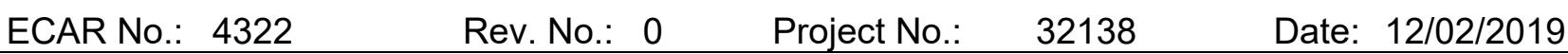

\begin{tabular}{|c|l|c|}
\hline 1. & $\begin{array}{l}\text { Does this ECAR involve } \\
\text { a Safety SSC? }\end{array}$ & No \\
\cline { 1 - 2 } 2. & $\begin{array}{l}\text { Safety SSC } \\
\text { Determination Document } \\
\text { ID }\end{array}$ & See LWP-10010 for requirements. \\
\cline { 1 - 2 } 3. & Engineering Job (EJ) No. & NA \\
\cline { 1 - 2 } 4. & SSC ID & NA \\
\hline 5. & Building & IRC \\
\cline { 1 - 2 } 6. & Site Area & REC \\
\hline
\end{tabular}

7. Objective/Purpose:

The purpose of this engineering calculations and analysis report (ECAR) is to present data collected in the Baseline Graphite Characterization Program, which is directly tasked with supporting the Idaho National Laboratory's (INL's) research and development efforts on the Advanced Reactor Technologies (ART) Program. This program populates a comprehensive database that reflects the baseline properties of nuclear-grade graphite with regard to individual grade, billet, and position within individual billets. The physical- and mechanical-property information being collected will be transferred to the Nuclear Data Management and Analysis System (NDMAS), and that database will help populate the handbook of property data available to member nations of the Generation-IV International Forum.

Transfer of these data from the applicable technical lead to the dissemination databases available to other end users requires a full review of the test procedures and data-collection efforts through an analysis of the multiple summary spreadsheets and values being collected. This report represents the analysis for 2114 Billet A20570 and facilitates release of associated data to the NDMAS custodians.

8. If revision, please state the reason and list sections and/or pages being affected:

NA

9. Conclusions/Recommendations:

A review of data spreadsheets compiled from physical- and mechanical-property measurements on nuclear-grade graphite 2114 Billet A20570 revealed no notable errors or omissions that preclude the transfer of these data to the NDMAS site for storage.

In addition to a full visual review of data files to determine whether obvious errors, such as missing information, were made regarding the data collected, graphical representations were made of individual evaluations in order to provide a means to identify anomalies. The techniques employed are an adequate means to ensure the comprehensive data collected reflect the intended values of interest. A review of the data indicates that the files, as submitted, are fully representative of the measured properties of graphite billets being tested, as outlined in the applicable test procedures and program plans. 
Rev. 08

Title: $\quad$ Baseline Characterization Database Verification Report - 2114 Billet A20570

$\begin{array}{lllll}\text { ECAR No.: } 4322 & \text { Rev. No.: } 0 & \text { Project No.: } 32138 \quad \text { Date: } 12 / 02 / 2019\end{array}$

\section{CONTENTS}

SIGNATURES

SCOPE AND BRIEF DESCRIPTION

DESIGN OR TECHNICAL PARAMETER INPUT AND SOURCES 5

RESULTS OF LITERATURE SEARCHES AND OTHER BACKGROUND DATA 5

ASSUMPTIONS

COMPUTER CODE VALIDATION

DISCUSSION/ANALYSIS

$\begin{array}{lr}\text { Introduction } & 6\end{array}$

$\begin{array}{lr}\text { Database Analysis } & 6\end{array}$

Compression Specimen Database (2114 A20570) 8

Electrical Resistivity, Modulus, Coefficient of Thermal Expansion 11

$\begin{array}{ll}\text { Density Values } & 14\end{array}$

$\begin{array}{ll}\text { Flexural Specimen Database (2114 A20570) } & 15\end{array}$

$\begin{array}{ll}\text { Density Values } & 19\end{array}$

Tensile Specimen Database (2114 A20570T) 21

$\begin{array}{ll}\text { REMACHINED SPECIMEN PROPERTIES } & 24\end{array}$

REMACHINED SPLIT DISC TESTING 24

$\begin{array}{ll}\text { REMACHINED SPECIMEN DIFFUSIVITY } & 26\end{array}$

$\begin{array}{ll}\text { SUMMARY } & 26\end{array}$

$\begin{array}{lr}\text { REFERENCES } & 27\end{array}$

Appendix A Additional Compression Specimen Database Plots (2114 A20570) A-1

Appendix B Additional Flexural Specimen Database Plots (2114 A20570) B-1

Appendix C Additional Tensile Specimen Database Plots (2114 A20570) C-1 
TEM-10200-1

Rev. 08

Title: $\quad$ Baseline Characterization Database Verification Report - 2114 Billet A20570

ECAR No.: 4322

Rev. No.: 0

Project No: :

32138

Date: $12 / 02 / 2019$

PROJECT ROLES AND RESPONSIBILITIES

\begin{tabular}{lllll}
\multicolumn{1}{c}{ Project Role } & \multicolumn{1}{c}{ Name (Typed) } & Organization & Pages covered (if applicable) \\
\hline $\begin{array}{l}\text { Performer } \\
\text { Checker }\end{array}$ & David Rohrbaugh & D520 & All \\
Independent Reviewer & W. David Swank & B612 & All & \\
$\begin{array}{l}\text { CUI Reviewer } \\
\text { Manager }\end{array}$ & NA & Robert Caliva & D520 & \\
$\begin{array}{l}\text { Requestore } \\
\text { Nuclear Safetye }\end{array}$ & William Windes & B612 & \\
Document Ownere & WA & & \\
\hline
\end{tabular}

\section{Responsibilities:}
a. Confirmation of completeness, mathematical accuracy, and correctness of data and appropriateness of assumptions.
b. Concurrence of method or approach. See definition, LWP-10106.
c. Concurrence with the document's markings in accordance with LWP-11202.
d. Concurrence of procedure compliance. Concurrence with method/approach and conclusion.
e. Concurrence with the document's assumptions and input information. See definition of Acceptance, LWP-10200.

NOTE: $\quad$ Delete or mark "N/A" for project roles not engaged. Include ALL personnel and their roles listed above in the eCR system. The list of the roles above is not all inclusive. If needed, the list can be extended or reduced. 
TEM-10200-1

$12 / 19 / 17$

Rev. 08

ENGINEERING CALCULATIONS AND ANALYSIS

Title: $\quad$ Baseline Characterization Database Verification Report - 2114 Billet A20570

ECAR No.: 4322

Rev. No.: 0

Project No.:

32138

Date: $12 / 02 / 2019$

\section{SIGNATURES}

$$
\begin{aligned}
& \text { Performer: } \frac{\text { David Rohrbaugh }}{\text { (Name) }} \frac{\text { D520 }}{\text { (Organization) }} \frac{11 / 14 / 20 / \%}{\text { (Dignate) }} \\
& \text { Checker: } \frac{\text { W. David Swank }}{\text { (Name) }} \frac{\text { B612 }}{\text { (Organization) }} \frac{1 \mathrm{c} / 19 / 19}{\text { (Date) }} \\
& \text { Independent Peer } \frac{\text { NA }}{(\text { Name })} \frac{}{\text { (Organization) }} \frac{}{\text { (Signature) }} \frac{}{\text { (Date) }} \\
& \text { Reviewer }{ }^{2} \text { : } \\
& \text { NA } \\
& \text { CUI Reviewer: } \\
& \text { Yes } \square \text { or } \mathrm{No}^{5} \square \\
& \text { (Name) } \\
& \overline{\text { (Organization) }} \\
& \text { (Signature) } \\
& \text { Manager: } \frac{\text { Robert Caliva }}{\text { (Name) }} \frac{\text { D520 }}{\text { (Organization) }} \frac{11 / 14 / 2019}{\text { (Date) }} \\
& \text { (Date) } \\
& \text { Owner: } \frac{\text { William Windes }}{\text { (Name) }} \frac{\text { B612 }}{\text { (Organization) }} \frac{11 / 19 / 20195}{\text { (Date) }} \\
& \text { Nuclear Safety }{ }^{4}: \frac{\text { NA }}{\text { (Name) }} \frac{}{\text { (Organization) }} \frac{}{\text { (Signature) }}
\end{aligned}
$$

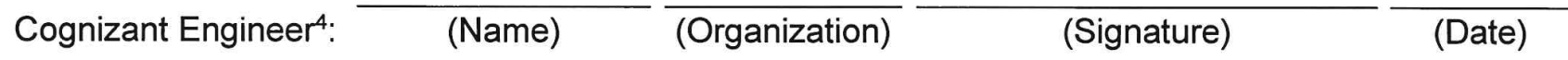

$$
\begin{aligned}
& \text { Quality Assurance: } \frac{\text { Michelle T. Sharp }}{\text { (Name) }} \frac{H 330 / C 601}{\text { (Organization) }} \frac{h \text { D Dhauge }}{\text { (Signature) }} \frac{12|z| c 9}{\text { (Date) }}
\end{aligned}
$$


TEM-10200-1

$12 / 19 / 17$

Rev. 08

ENGINEERING CALCULATIONS AND ANALYSIS

Page 5 of 28

Title: $\quad$ Baseline Characterization Database Verification Report - 2114 Billet A20570

ECAR No.: $4322 \quad$ Rev. No.: $0 \quad$ Project No.: $32138 \quad$ Date: $12 / 02 / 2019$

\section{SCOPE AND BRIEF DESCRIPTION}

This ECAR provides the results of a validity evaluation of the physical- and mechanical-property data collected on a billet of nuclear-grade graphite (i.e., 2114 Billet A20570) in support of the ART Baseline Graphite Characterization Program. ${ }^{1,2}$ Millions of raw data points have been collected during testing and quantification analyses for these billets. The summary scalar property values and supplementary traceability data are collected into comprehensive spreadsheets. Data sets are composed of single billets of graphite for any given grade, organized by mechanical test-specimen type, and further subdivided into individual spreadsheet tabs according to the specific test or evaluation being performed.

A direct analysis of properties was not conducted, and this report does not provide information on the validity or performance characteristics of the graphite itself. Rather, this report is intended as a verification of the completeness of actual data collected in accordance with PLN-3467, "Baseline Graphite Characterization Plan: Electromechanical Testing,"3 and their representation of the measurement and test results with sole regard to the graphite billets under evaluation.

\section{DESIGN OR TECHNICAL PARAMETER INPUT AND SOURCES}

Mechanical- and physical-property testing is carried out in accordance with PLN-3348, "Graphite Mechanical Testing"2; PLN-3467, "Baseline Graphite Characterization Plan: Electromechanical Testing"3; and PLN-3267, "AGC-2 Characterization Plan."4

\section{RESULTS OF LITERATURE SEARCHES AND OTHER BACKGROUND DATA}

None.

\section{ASSUMPTIONS}

None.

\section{COMPUTER CODE VALIDATION}

Data collection and storage are organized as reported in PLN-3467 and INL/EXT-10-19910, Baseline Graphite Characterization: First Billet. ${ }^{5}$ The individual computers being used run Windows 7 operating systems and store data on Microsoft Office Excel 2007 spreadsheets.

Control of individual test equipment is carried out by proprietary Netzsch software (IRC C-20) or Instron's Bluehill (Version 2) software (load frames in IRC B-11). Both software suites are commercially available packages. Updates, data transfers, and integrations are handled outside of INL's network system on a dedicated local area network.

The comprehensive interface between data collection, evaluation, and storage computers is handled through the customized LabVIEW-based Graphite Mechanical Properties Data Acquisition Software (Version 4.0). The Baseline Graphite Characterization Program's version control and operability checks are documented and validated in a registered laboratory notebook, LAB 2143, "Baseline Graphite Characterization."6 Validation of commercial packages is handled via integrated system checks specific to each new element or upgrade, as appropriate. 
TEM-10200-1

$12 / 19 / 17$

ENGINEERING CALCULATIONS AND ANALYSIS

Page 6 of 28

Rev. 08

Title: $\quad$ Baseline Characterization Database Verification Report - 2114 Billet A20570

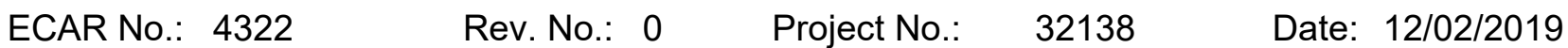

\section{DISCUSSION/ANALYSIS}

\section{Introduction}

The ART Project Graphite Research and Development Program generates the extensive quantitative data necessary for predicting behavior and operating performance of available nuclear graphite grades. To determine in-service behavior of graphite for the latest proposed designs, two main programs are underway. The first, the Advanced Graphite Creep (AGC) Program, provides a set of tests that are designed to evaluate the irradiated properties and behavior of nuclear-grade graphite over a large spectrum of conditions, based on the operating environment of the very-high-temperature reactor core. ${ }^{1}$ A limited amount of data can be generated on irradiated material because of the availability of space within the Advanced Test Reactor and the geometric constraints placed on the AGC specimens that will be inserted into the reactor. To supplement the AGC data set, the Baseline Graphite Characterization Program provides additional data that will characterize inherent property variability in nuclear-grade graphite without the testing constraints of the AGC Program. ${ }^{2}$ This variability in properties is a natural artifact of graphite due to the geologic raw materials that are used in its production. This variability is quantified, not only within a single billet of as-produced graphite, but also from billets within a single lot, billets from different lots of the same grade, and across different billets of numerous grades of currently available nuclear graphite.

This report covers the release of physical- and mechanical-property data from a billet of 2114 graphite. Graphite Billet 2114 A20570 is a block of isomolded graphite with a medium grain structure. The baseline mechanical properties database for this billet, plots of which are included throughout this report, is composed solely of scalar results from each of the different evaluations (i.e., mechanical testing and physical properties) in summary form, and comprises tabbed spreadsheets occupied by more than 60,000 cells of individual characteristics or property values and associated tagging information.

This report is intended as a validation review of Graphite Billet 2114 A20570. The report is not an analysis of property characteristics or trends beyond the evaluation necessary to determine whether the collected data are reflective of the properties of this particular graphite billet. The report is an acceptance of the test methods used and data calculations and conversions carried out and a review of values from the standpoint of determining whether they reflect anomalous behavior that must be further investigated.

Ultimately, this report provides justification for transfer of this data set into a storage and analysis system that is available for internal and external analysts to utilize in evaluating the relevant characteristics and performance of nuclear-grade graphite.

\section{Database Analysis}

The data sets being generated for the Baseline Graphite Characterization Program consist of properties collected on standard American Society of Testing and Materials (ASTM) international-based mechanical test specimens, as shown in Figure 1. Details of specimen tracking, traceability, process flow, and the techniques being employed to facilitate those activities are provided in INL/EXT-10$19910 .{ }^{5}$ For ease of reviewing the applicable data in this report, an example of a sectioning diagram for 2114 graphite, along with the applicable specimen identification codes, is provided in Figure 2 . This 
TEM-10200-1

$12 / 19 / 17$

ENGINEERING CALCULATIONS AND ANALYSIS

Page 7 of 28

Rev. 08

Title: $\quad$ Baseline Characterization Database Verification Report - 2114 Billet A20570

$\begin{array}{lllll}\text { ECAR No.: } 4322 & \text { Rev. No.: } 0 & \text { Project No.: } 32138 \quad \text { Date: 12/02/2019 }\end{array}$

figure is representative of a quarter of a single sub-wedge of graphite from this billet. Detailed drawings of 2114 graphite billet sectioning can be found in INL drawings 778681 and 781082

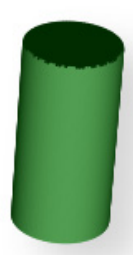

Compressive Specimen

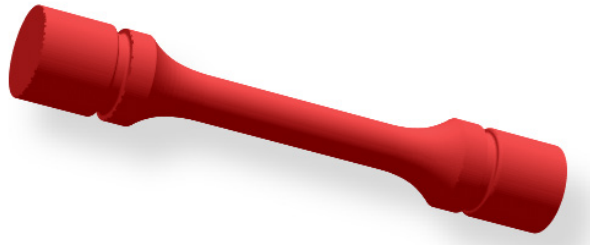

Tensile Specimen

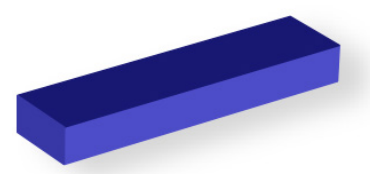

Flexural

Specimen

Figure 1. The three types of mechanical test specimens that will be machined from stock graphite and provide the basis for material property evaluations.
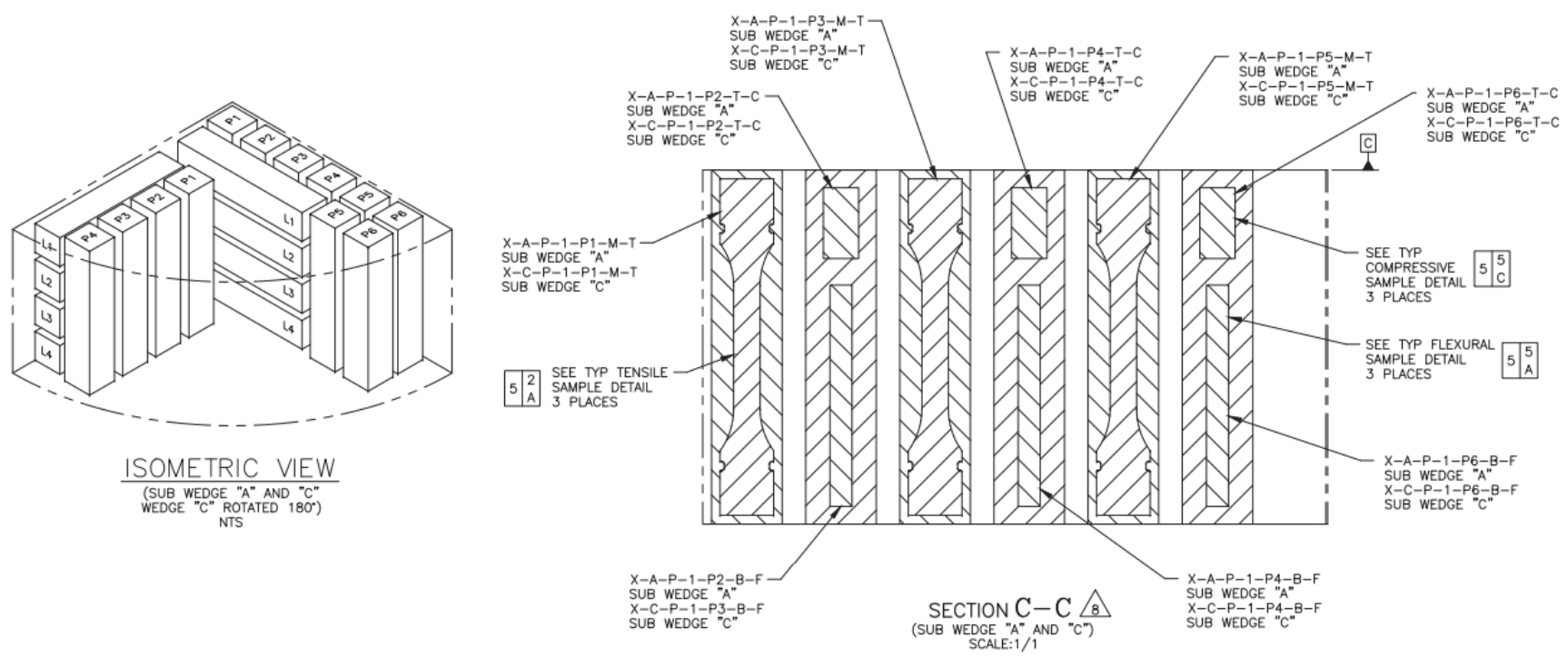

Figure 2. Individual specimen extraction and tracking identification from 2114 Billet A20570.

Sections of this report cover each of the individual databases for this billet, are divided by mechanical test-specimen type (i.e., compressive, flexural, or tensile), and are organized so they present data in graphical form. Graphic representations are not sorted in any way aside from the actual order in which they were tested, which was randomized for the express purpose of minimizing test anomalies based on actual test timeframes. Some expectation of variation in the property values exists, but individual data points that fall within a reasonable property value range are considered acceptable. Comparisons of extreme values with other associated properties (e.g., a comparison of maximum tensile load values with measured strain to determine whether they are related by the expected elastic modulus) are carried out where applicable. Each of these comparisons and analyses may not be explicitly included in this report. However, the process-control charts with standard-deviation values and/or property-trend charts for the various characteristics being measured are included both in this section as well as the appendices $( \pm 1,2$, and 3 standard deviations are represented by the yellow, orange, and red dotted lines, and the mean is represented by the green line). 
TEM-10200-1

$12 / 19 / 17$

ENGINEERING CALCULATIONS AND ANALYSIS

Page 8 of 28

Rev. 08

Title: $\quad$ Baseline Characterization Database Verification Report - 2114 Billet A20570

$\begin{array}{lllll}\text { ECAR No.: } 4322 & \text { Rev. No.: } 0 & \text { Project No.: } 32138 \quad \text { Date: 12/02/2019 }\end{array}$

A goal of the Baseline Graphite Characterization Program is to identify and quantify interbillet variation. However, the focus of this analysis is to compare values from complete data sets to quickly identify outlying points. One example would be a zero value for a specific property-quickly identifiable on a test result trend graph-providing an indication that the specific spreadsheet cell is improperly empty. Another example would be a large disparity between a limited number of points on that same test-result trend graph that results from missing values in other cells (i.e., dimensional measurements from which final properties are calculated). This verification will couple those observations with a comprehensive data scan of individual points to determine whether the data set can be considered complete and the scalar summary points provided to the NDMAS are appropriately representative of the billet under evaluation.

\section{Compression Specimen Database (2114 A20570)}

\section{Compression Testing}

Compression testing was performed per ASTM C695-157 and PLN-3467. Figure 3 shows the maximum applied load for each of the 111 compression specimens from Billet A20570. As was mentioned previously, some variation in graphite properties is expected, and this variation is reflected in the difference in test-frame loading. The compressive-strength values (Figure 4) correlate directly with recorded load values (Figure 3), confirming the stress calculations were performed correctly. An additional check of critical-property values is the measured deflection (Figure 5) of the loading surface, or upper platen, as measured by a calibrated deflectometer. Within geometric variations, the deflection should reflect the calculated compressive strain as shown in Figure 6 . Although Figure 5 and Figure 6 show a data point that lies outside of 3 standard deviations from the mean, there are no supporting data that necessitate the removal of this data point from the database. This slightly lower or slightly higher data point is therefore attributed to material variation or flaws within the specimens.

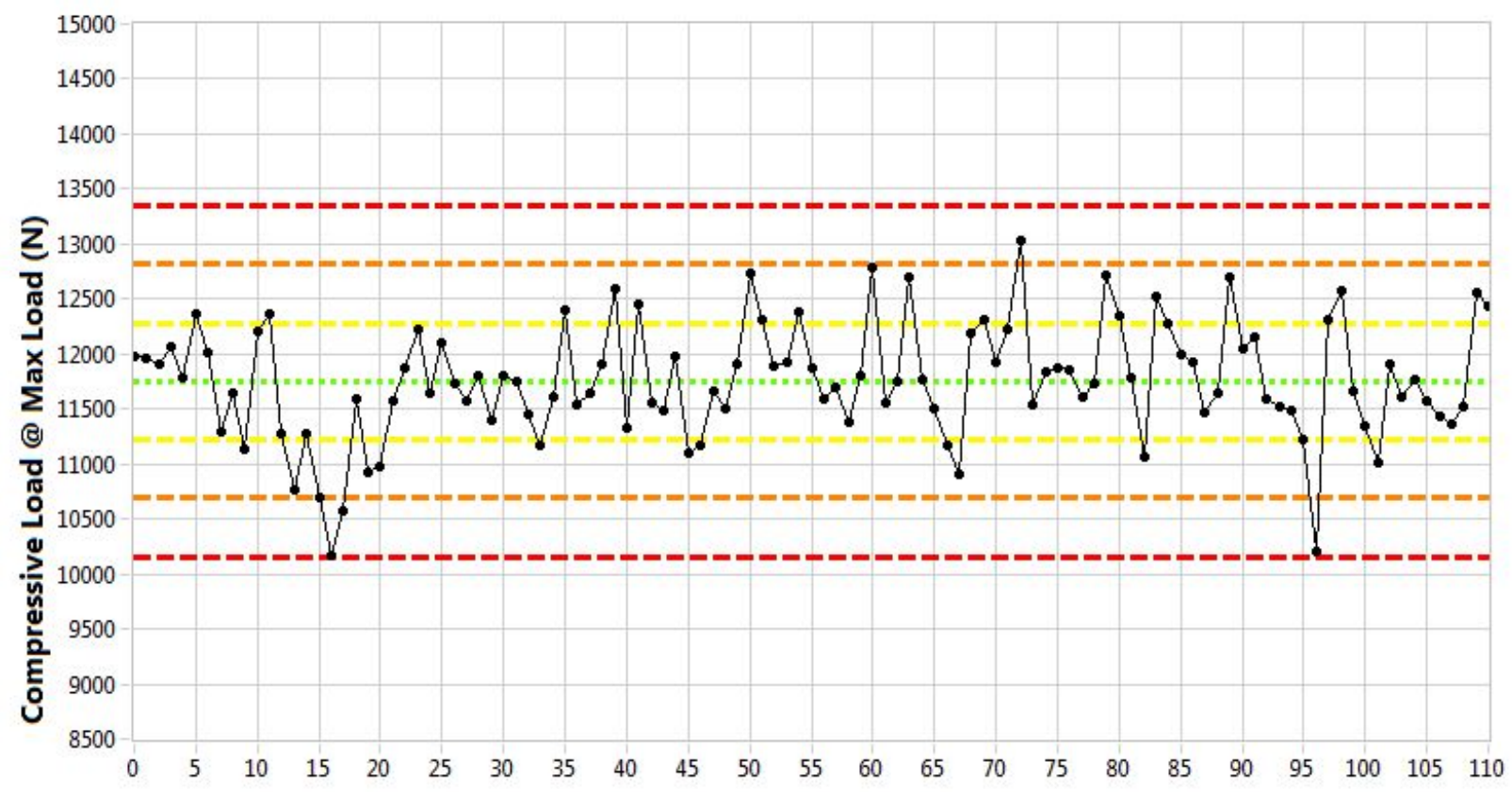

Figure 3. Compressive Load @ max load $(\mathrm{N})$, mean = 11753, standard deviation = 531 . 
TEM-10200-1

$12 / 19 / 17$

Rev. 08

Title: $\quad$ Baseline Characterization Database Verification Report - 2114 Billet A20570

ECAR No.: 4322

Rev. No.: $0 \quad$ Project No.: 32138

Date: $12 / 02 / 2019$

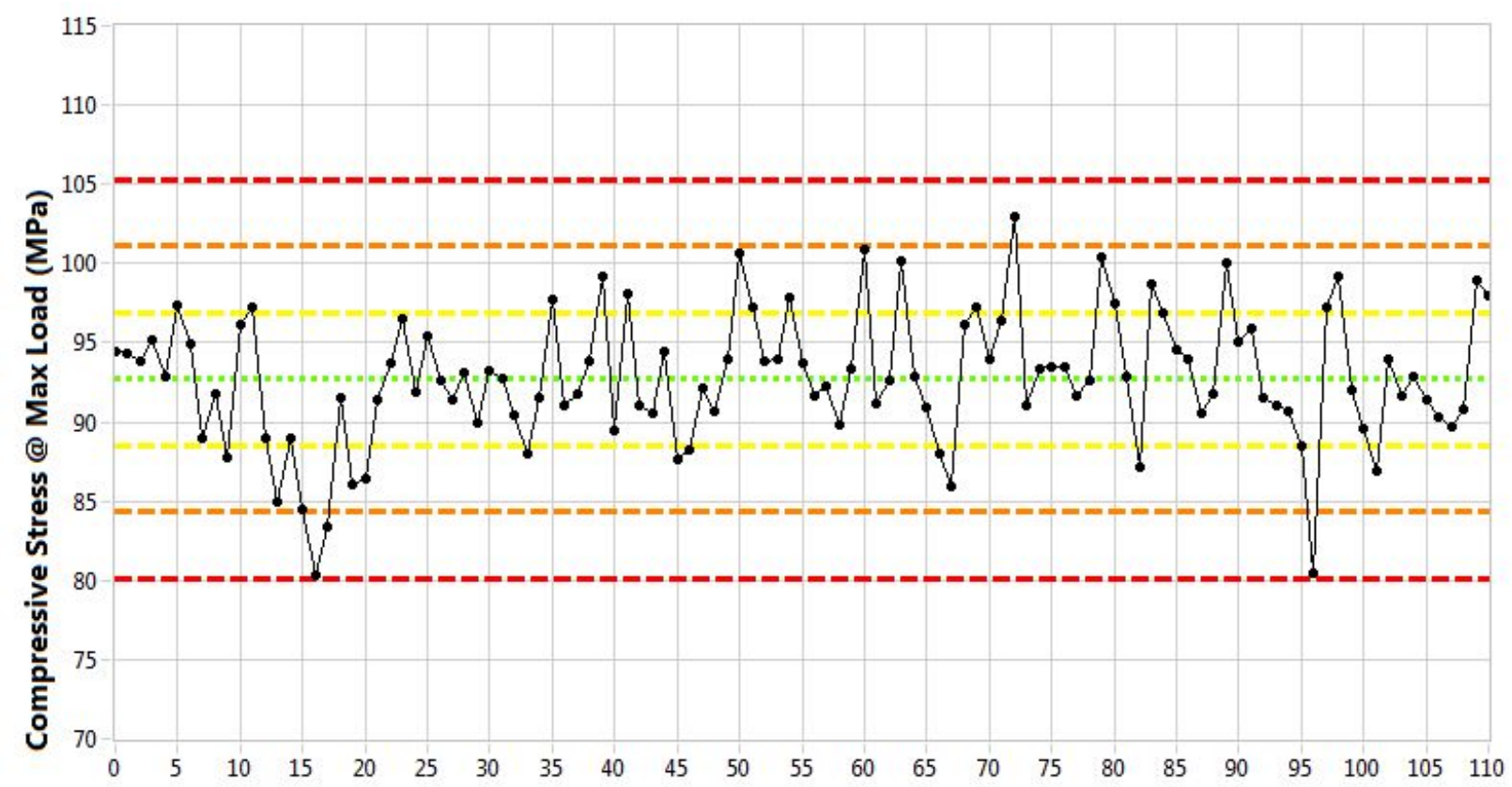

Figure 4. Compressive stress @ max load (MPa), mean= 92.7, standard deviation = 4.2.

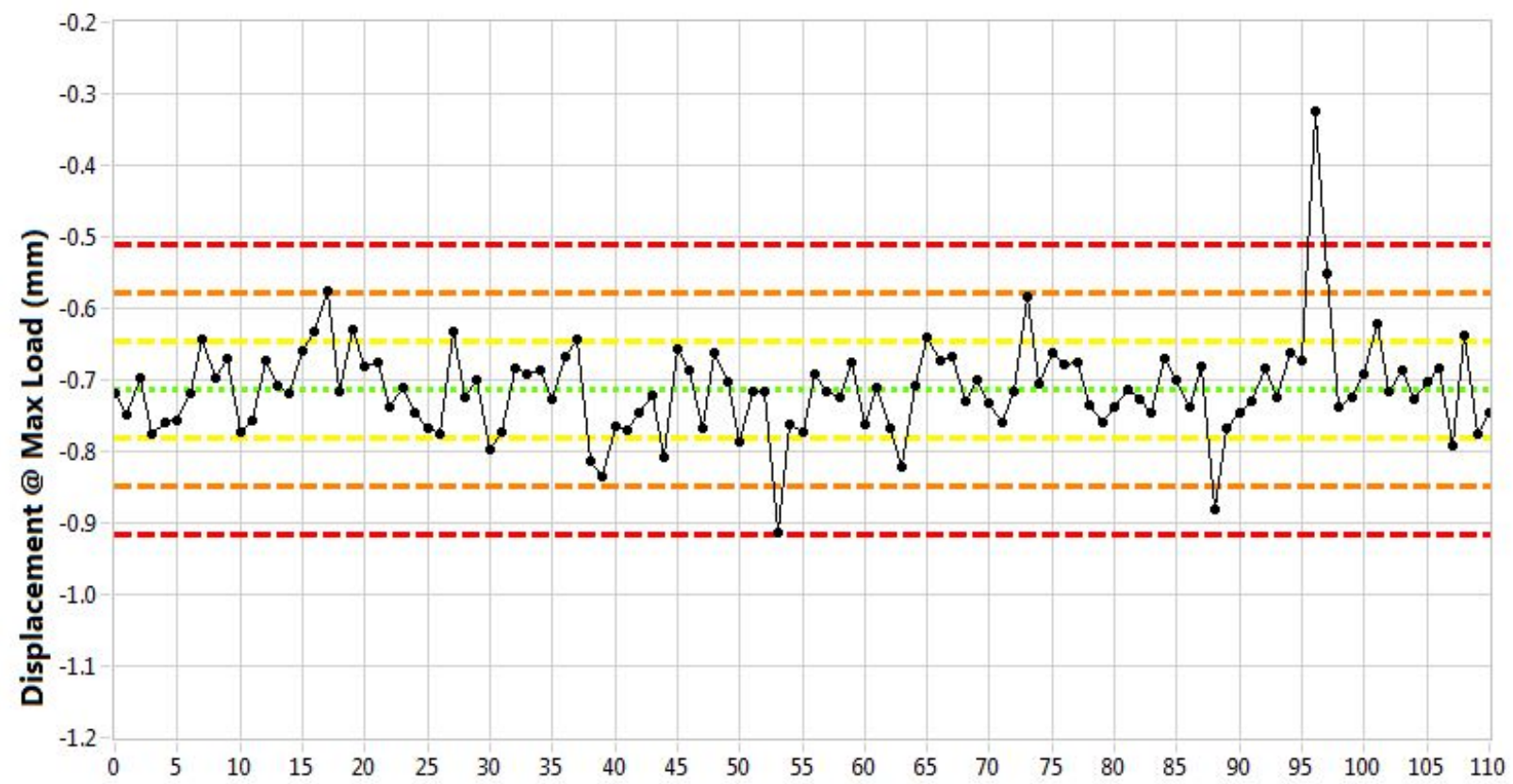

Figure 5. Displacement @ $\max$ load $(\mathrm{mm})$, mean = -0.7131, standard deviation $=0.0677$. 
TEM-10200-1

Rev. 08

Title: $\quad$ Baseline Characterization Database Verification Report - 2114 Billet A20570

$\begin{array}{lllll}\text { ECAR No.: } 4322 & \text { Rev. No.: } 0 & \text { Project No.: } 32138 & \text { Date: } 12 / 02 / 2019\end{array}$

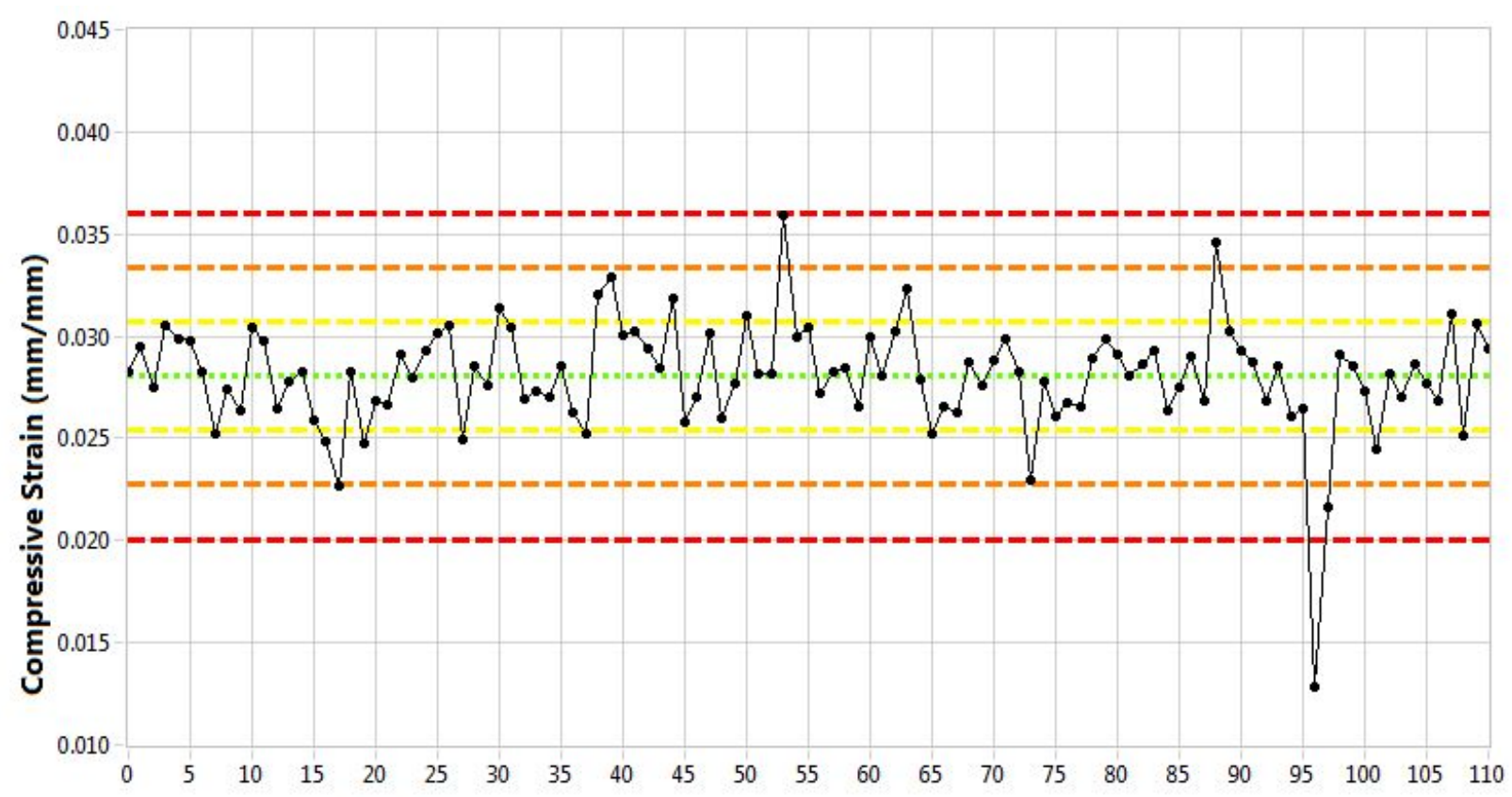

Figure 6. Compressive strain $(\mathrm{mm} / \mathrm{mm})$, mean $=0.0281$, standard deviation $=0.0027$.

\section{Fracture Surface Categorization}

Fracture surfaces from compressive specimens offer an additional opportunity to collect scalar data that can be sorted with respect to graphite type and position. To allow for consistency in what is essentially a qualitative attribute, a description of each of the fracture types is provided to the user of the Graphite Mechanical Properties Data Acquisition Software. Figure 7 is a screen shot of this categorization, along with the distribution of the recorded fracture categories for each of the 111 compressive specimens from 2114 Billet A20570 (with no anomalous values indicative of an unallowable characterization). 
Rev. 08

Title: $\quad$ Baseline Characterization Database Verification Report - 2114 Billet A20570

$\begin{array}{llllll}\text { ECAR No.: } 4322 & \text { Rev. No.: } & 0 & \text { Project No.: } & 32138 & \text { Date: } 12 / 02 / 2019\end{array}$

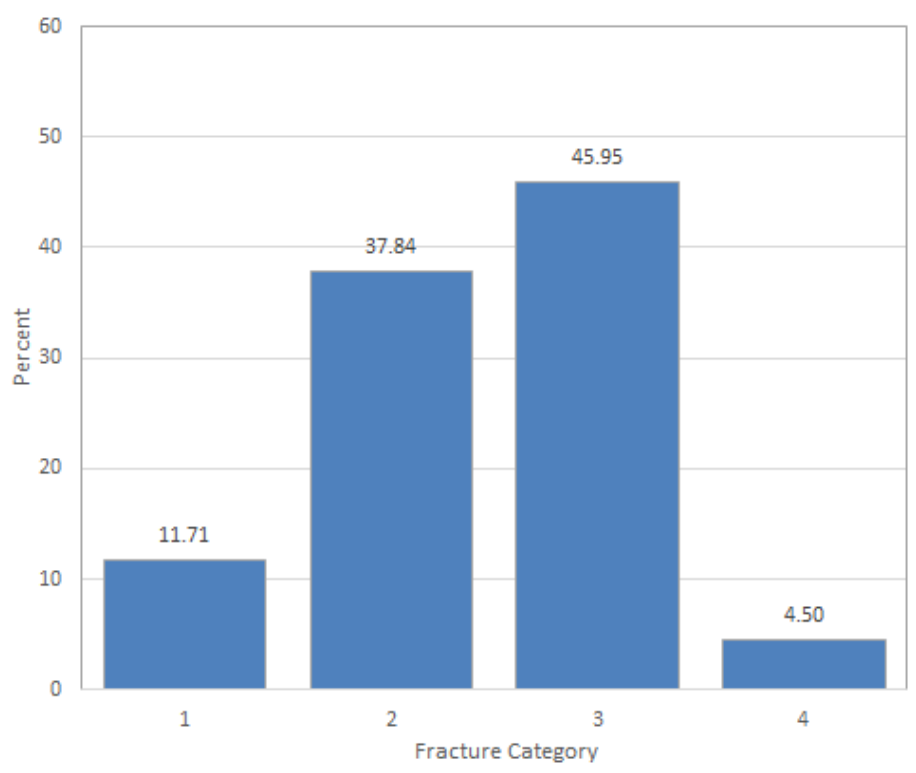

Fracture Category Descriptions

Category 1

Fracture initiates at the surface of the long axis from tensile forces as the outer fibers are strained, resulting in the loss of a wedge-shaped component from the specimen side. Ends often remain intact, and specimen may or may not be completely severed.

Category 2

Shear fracture with the major failure surface lying $55^{\circ}-65^{\circ}$

from the specimen ends. Fractures that fit this description but do not lie between $55^{\circ}$ and $65^{\circ}$ should be listed under Category 4 with the failure angle estimated to the nearest $5^{\circ}$.

\section{Category 3}

Fracture surface has a large portion lying parallel to the applied force (long axis direction). It will also regularly contain a shear fracture component, but the cleavage surface contains at least $50 \%$ of the overall specimen height.

\section{Category 4}

Any fracture condition not described by the other categories(i.e. specimen brittle fracture that leaves few major portions that can be classified) or a shear fracture that does not lie between $55^{\circ}$ and $65^{\circ}$. Fractures in this category must be described in the Comments section.

Figure 7. Fracture categorization results and description.

\section{Electrical Resistivity, Modulus, Coefficient of Thermal Expansion}

Electrical resistivity, Young's and shear modulus by sonic velocity, Young's modulus by sonic resonance, and coefficient of thermal expansion (CTE) tests were performed on the 60 compression specimens before they were broken. These tests were carried out via the appropriate ASTM standards. 9,10,11,12,13 Charts of those data are shown in Figure 8 through Figure 12. 
TEM-10200-1

$12 / 19 / 17$

Rev. 08

Title: $\quad$ Baseline Characterization Database Verification Report - 2114 Billet A20570

ECAR No:: 4322

Rev. No.: $0 \quad$ Project No.: 32138

Date: $12 / 02 / 2019$

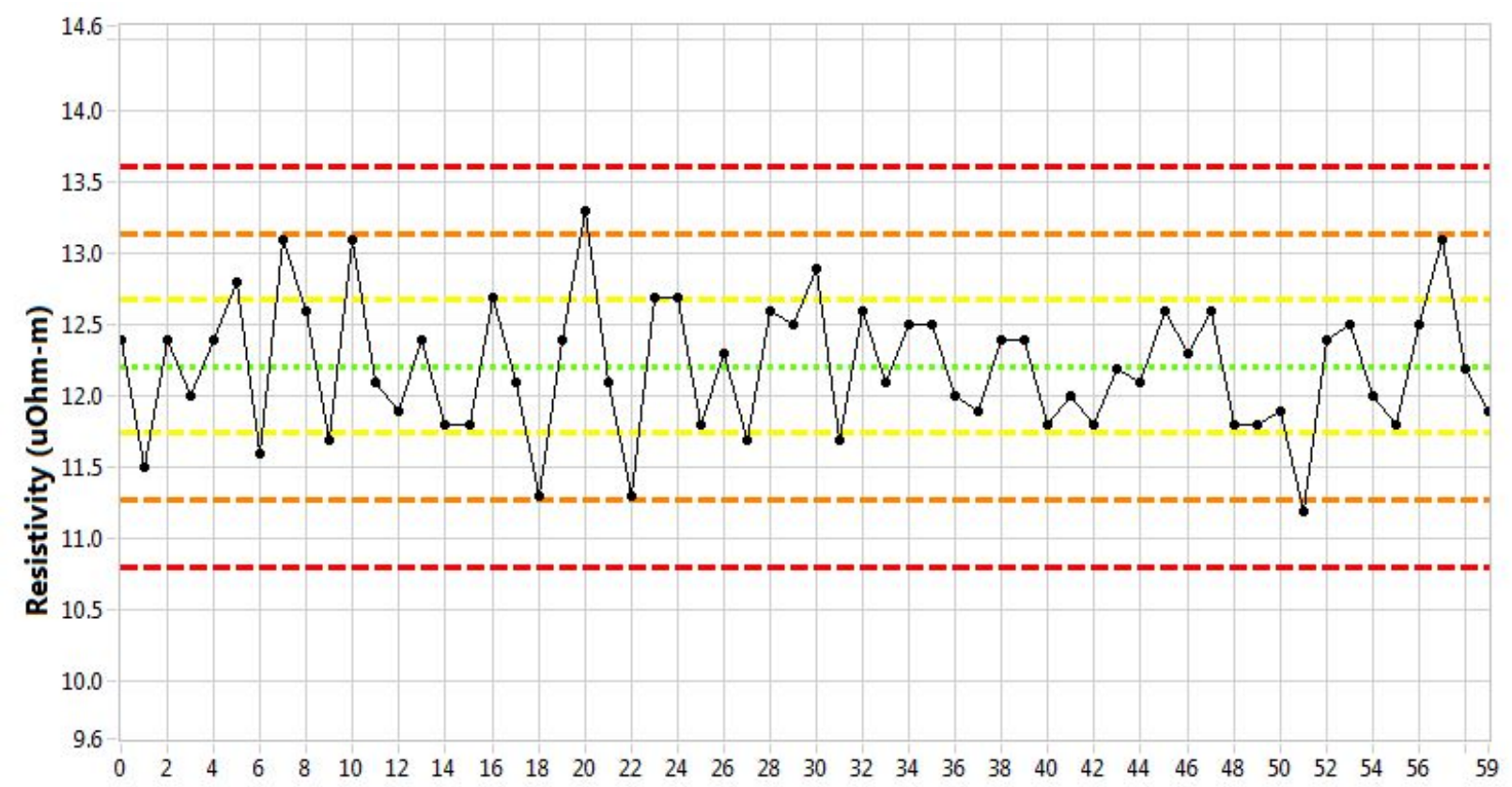

Figure 8. Electrical resistivity $(\mu \Omega-\mathrm{m})$, mean $=12.2$, standard deviation $=0.47$.

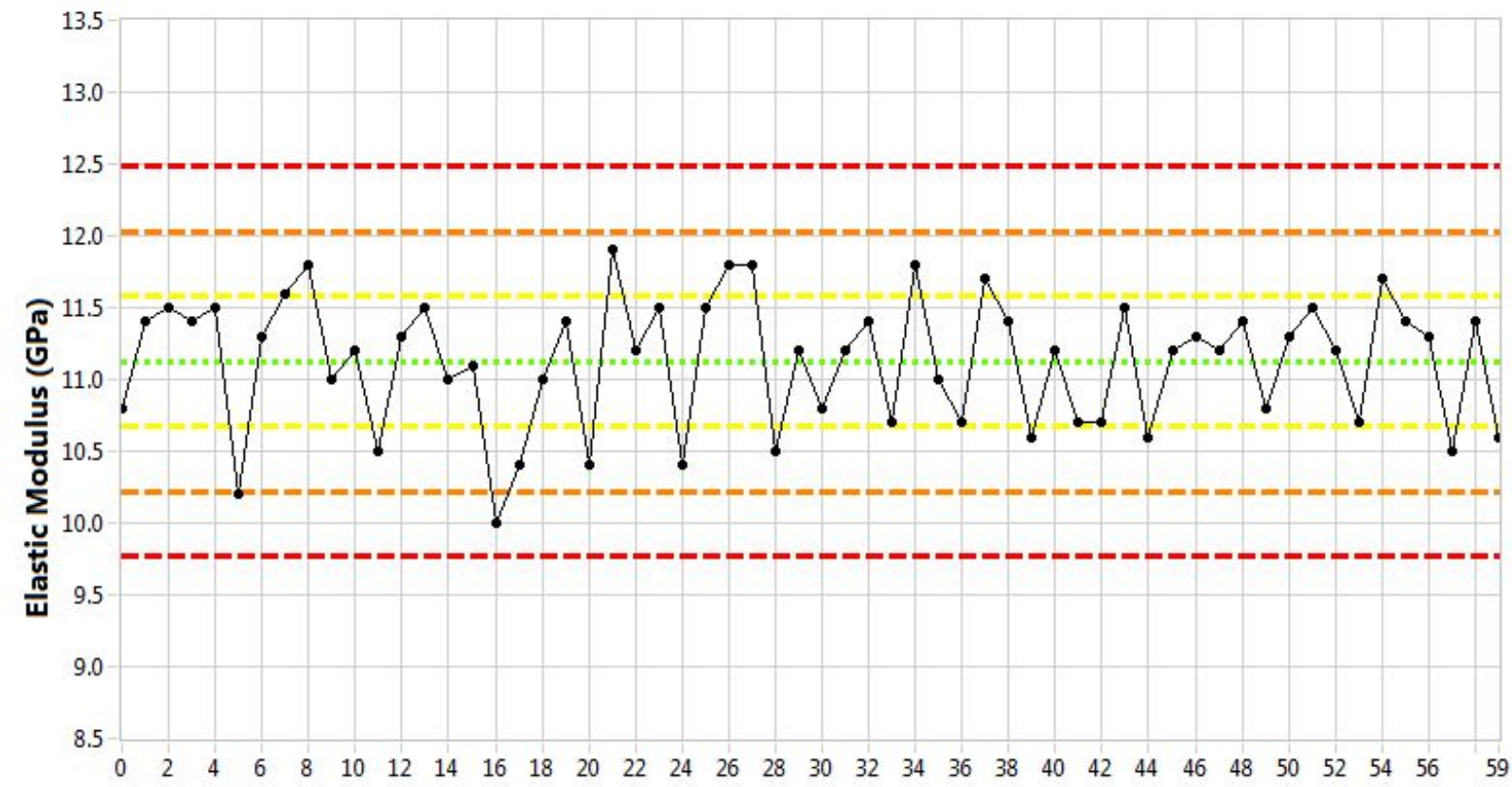

Figure 9. Young's modulus by sonic velocity method $(\mathrm{GPa})$, mean $=11.1$, standard deviation $=0.45$. 
TEM-10200-1

$12 / 19 / 17$

Rev. 08

Title: $\quad$ Baseline Characterization Database Verification Report - 2114 Billet A20570

ECAR No.: 4322

Rev. No.: $0 \quad$ Project No.: 32138

Date: $12 / 02 / 2019$

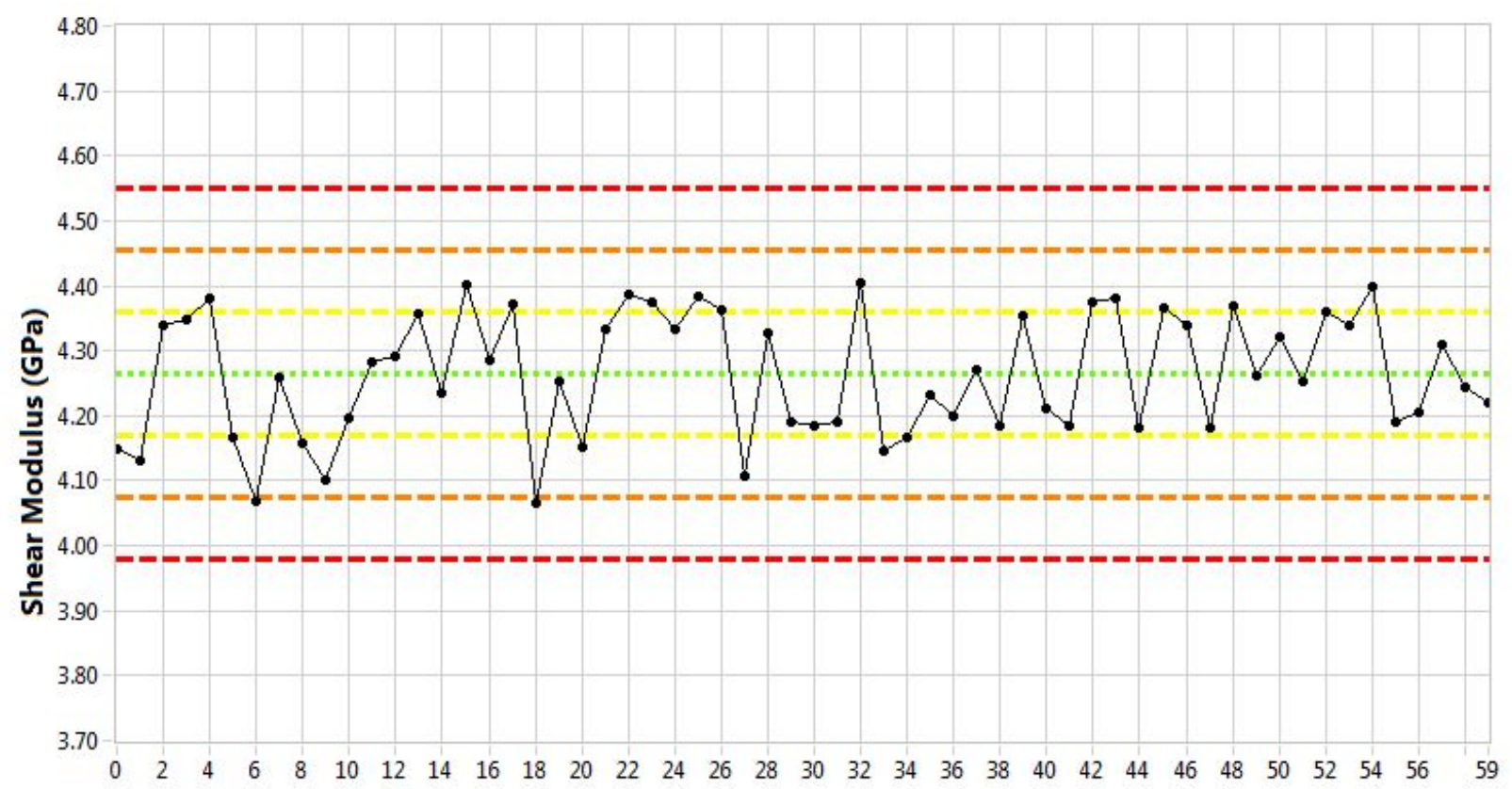

Figure 10. Shear modulus by sonic velocity method $(\mathrm{GPa})$, mean $=4.3$, standard deviation $=0.1$.

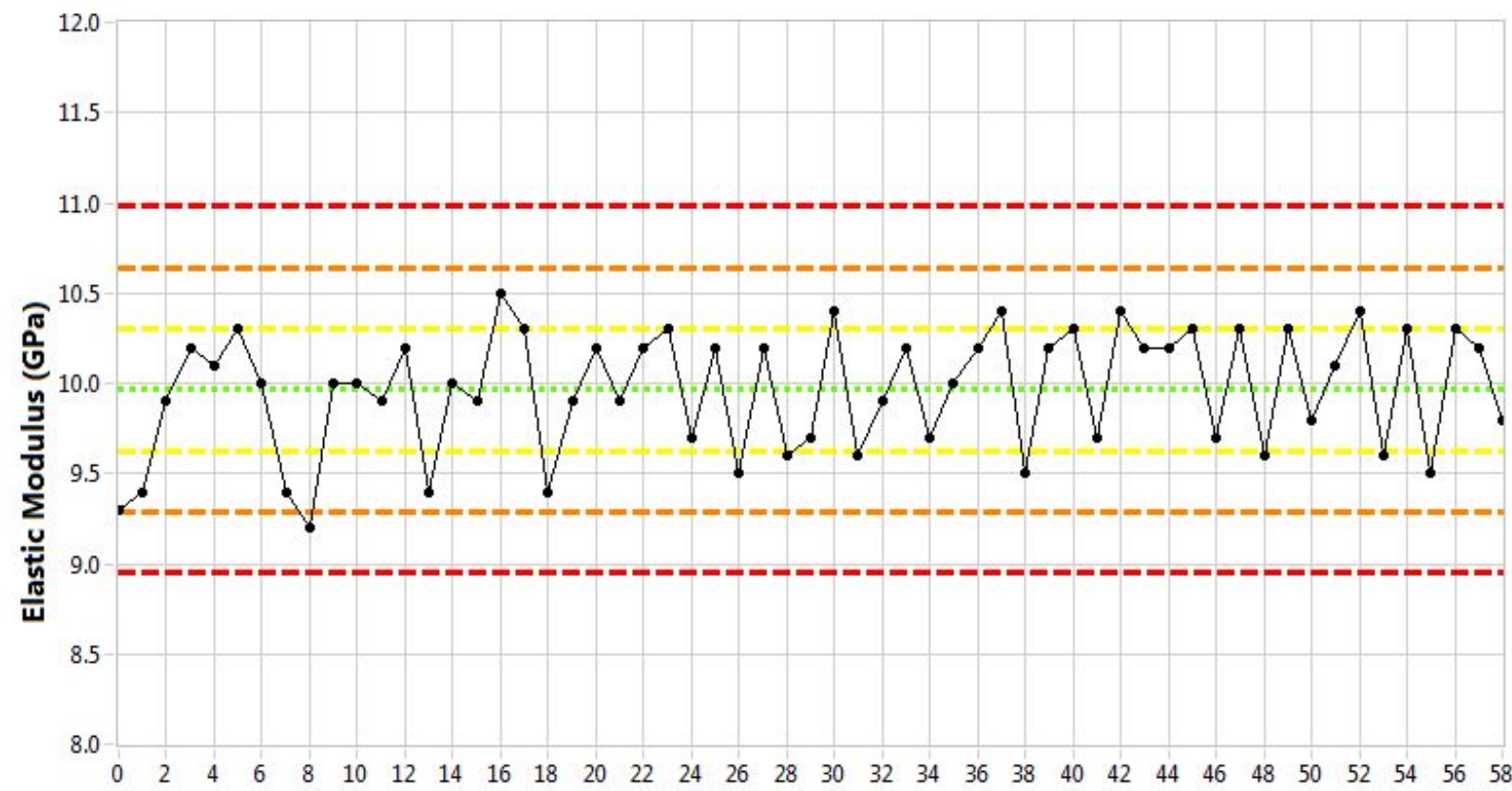

Figure 11. Elastic modulus by sonic resonance method $(\mathrm{GPa})$, mean $=10.0$, standard deviation $=0.34$. 
TEM-10200-1

Rev. 08

Title: $\quad$ Baseline Characterization Database Verification Report - 2114 Billet A20570

ECAR No.: 4322 Rev. No.: $0 \quad$ Project No.: 32138 Date: $12 / 02 / 2019$

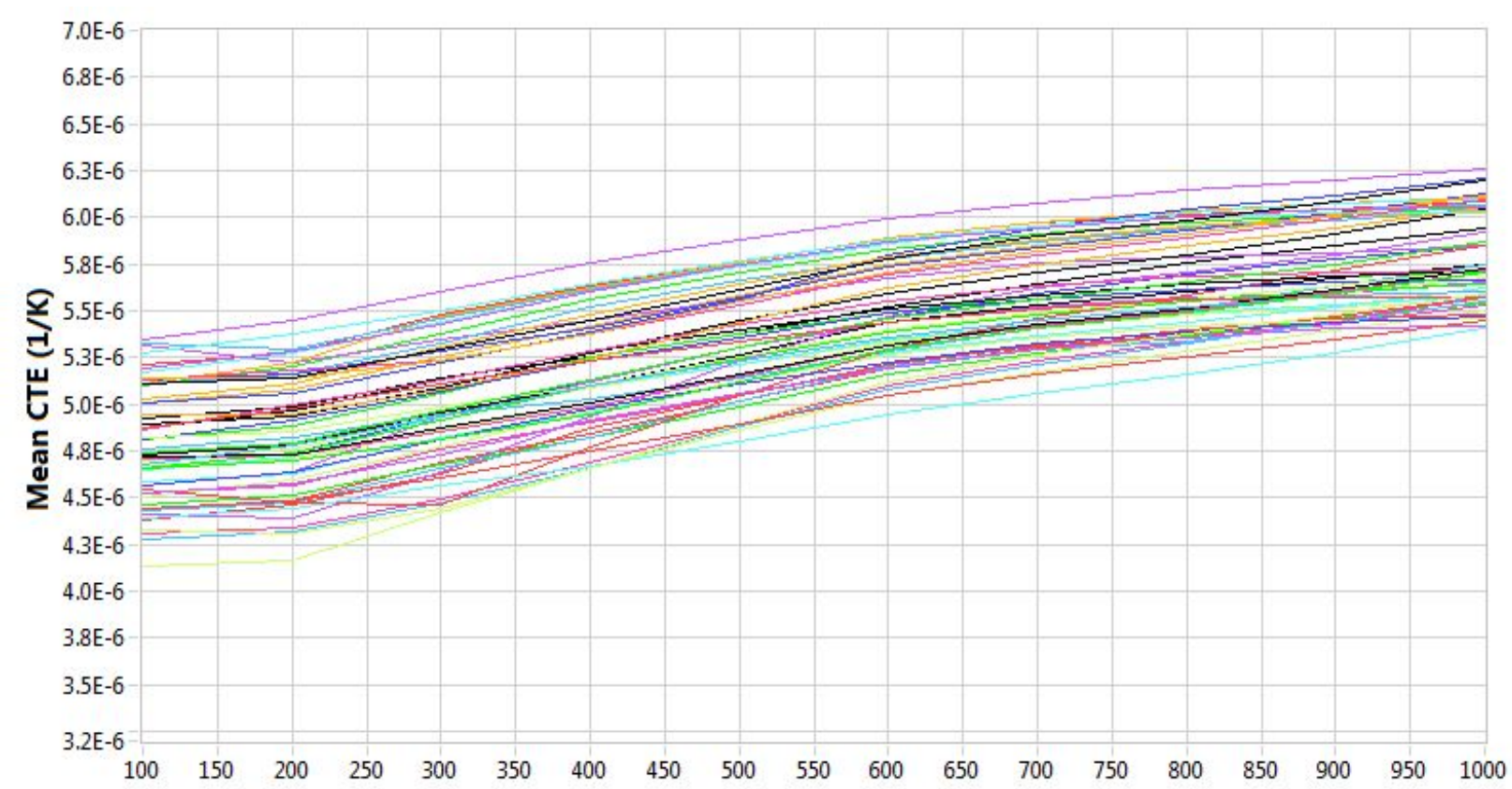

Figure 12. Mean CTE (1/K).

\section{Density Values}

The relatively simple geometric shape of the compressive specimens provides an opportunity to collect density data (per ASTM C559-9014) for a large portion of the specimens extracted from each billet. While not true performance properties, density measurements are relatively straightforward to collect and are often reflective of bulk mechanical properties. The density values recorded for the compression specimens (Figure 13) show no anomalous values other than the expected material and measurement variation. 
TEM-10200-1

$12 / 19 / 17$

Rev. 08

Title: $\quad$ Baseline Characterization Database Verification Report - 2114 Billet A20570

$\begin{array}{lllll}\text { ECAR No.: } 4322 & \text { Rev. No.: } 0 & \text { Project No.: } 32138 \quad \text { Date: } 12 / 02 / 2019\end{array}$

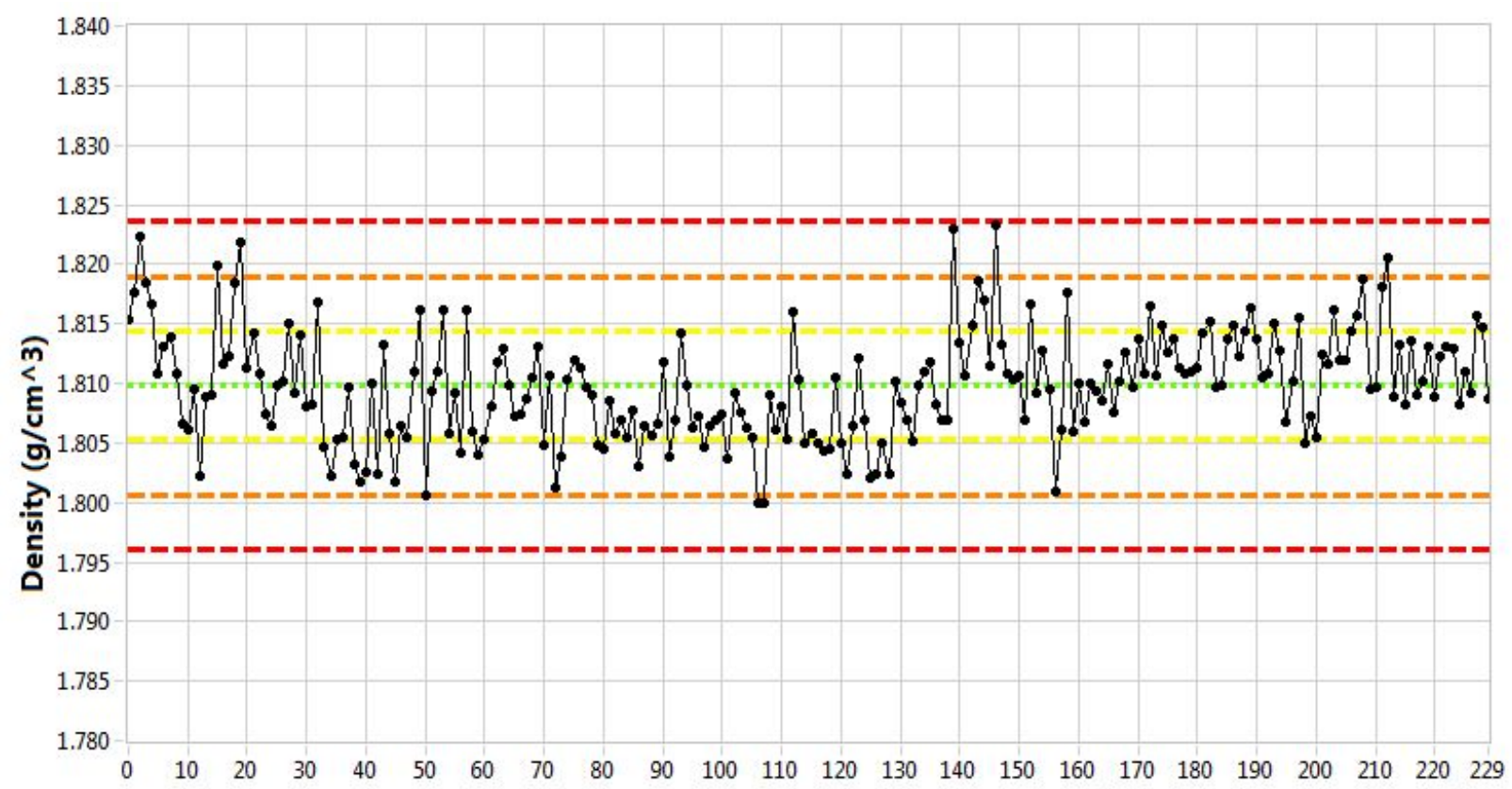

Figure 13. Density $\left(\mathrm{g} / \mathrm{cm}^{\wedge} 3\right)$, mean $=1.8098$, standard deviation $=0.0046$.

\section{Flexural Specimen Database (2114 A20570)}

\section{Flexural Testing}

Flexural testing was performed per ASTM C651-91,15 with clarifications to ambiguities in the standard identified in PLN-3467. ${ }^{3}$ As with the presentation of compression-specimen results, test validation lies not only in the documented adherence to applicable test plans and standards, but also in the noted correlations between recorded test properties and analyses for extreme or anomalous values. Additional verification of test conditions can be accomplished through an analysis of the physical characteristics of the specimens. Figure 14, Figure 15, and Figure 16 show the measured width, thickness, and length for all flexural specimens tested.

Figure 17 and Figure 18 show the relationship between flexural load and recorded flexural stress for the 190 specimens tested in flexure from 2114 Billet A20570. Further comparisons and verification can be made with measured deflection (Figure 19), which will reflect an additional correlation with stress values through material elastic constants. 
TEM-10200-1

$12 / 19 / 17$

Rev. 08

Title: $\quad$ Baseline Characterization Database Verification Report - 2114 Billet A20570

ECAR No.: 4322

Rev. No.: $0 \quad$ Project No.: 32138

Date: $12 / 02 / 2019$

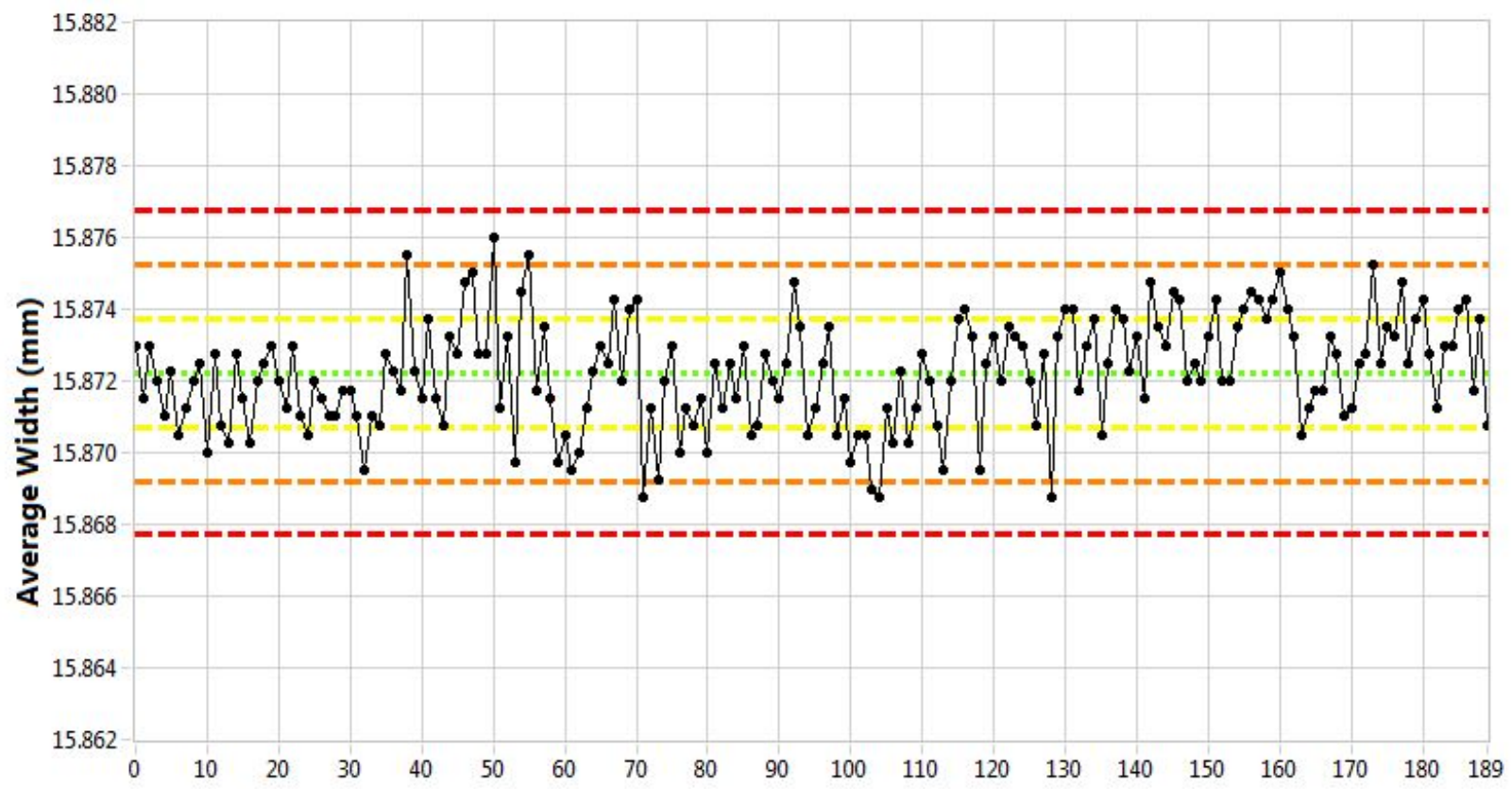

Figure 14. Average width $(\mathrm{mm})$, mean $=15.8722$, standard deviation $=0.0015$.

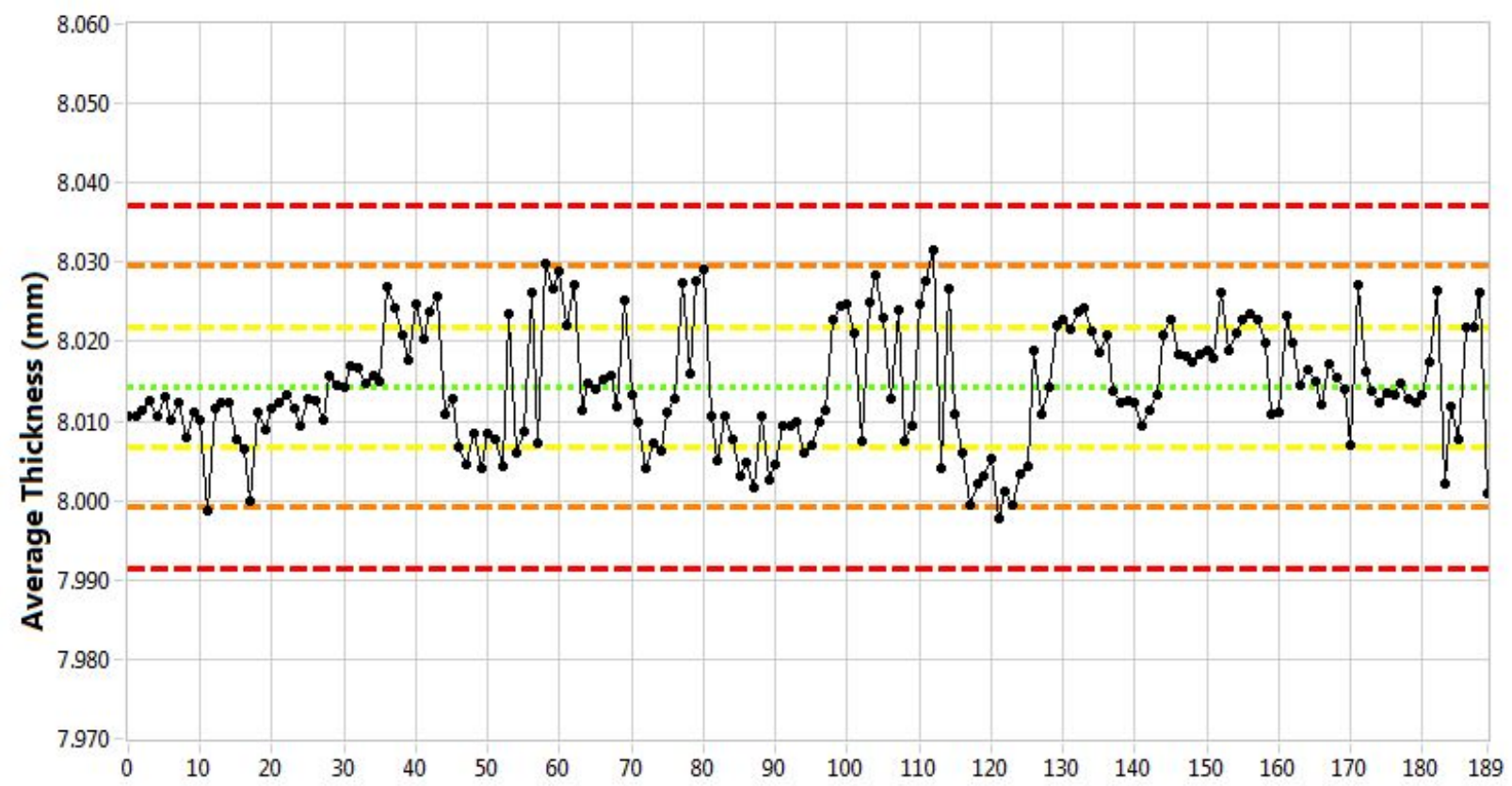

Figure 15. Average thickness $(\mathrm{mm})$, mean $=8.0143$, standard deviation $=0.0076$. 
TEM-10200-1

$12 / 19 / 17$

Rev. 08

Title: $\quad$ Baseline Characterization Database Verification Report - 2114 Billet A20570

ECAR No.: 4322

Rev. No.: $0 \quad$ Project No.: 32138

Date: $12 / 02 / 2019$

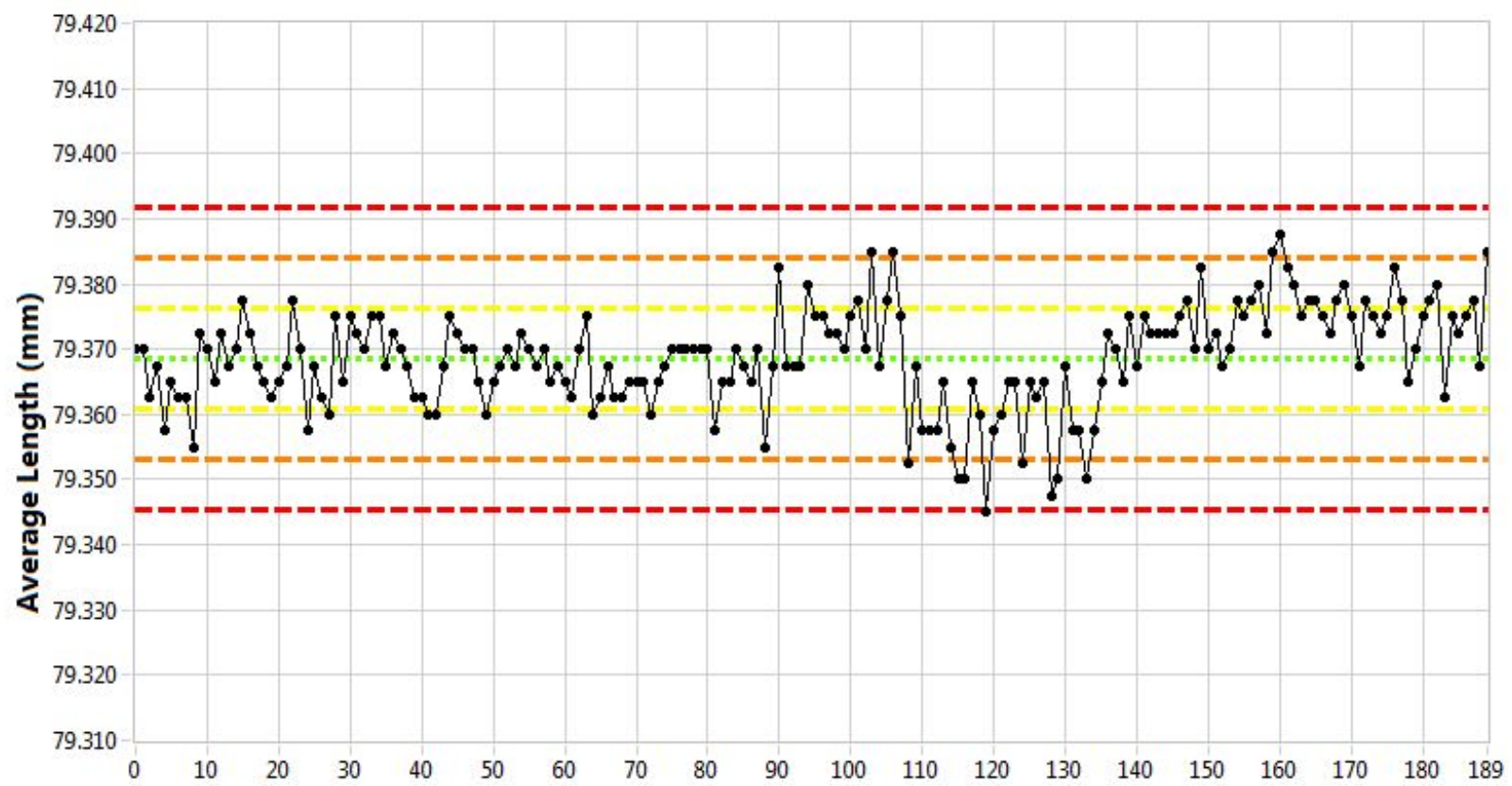

Figure 16. Average length $(\mathrm{mm})$, mean $=79.3686$, standard deviation $=0.0077$.

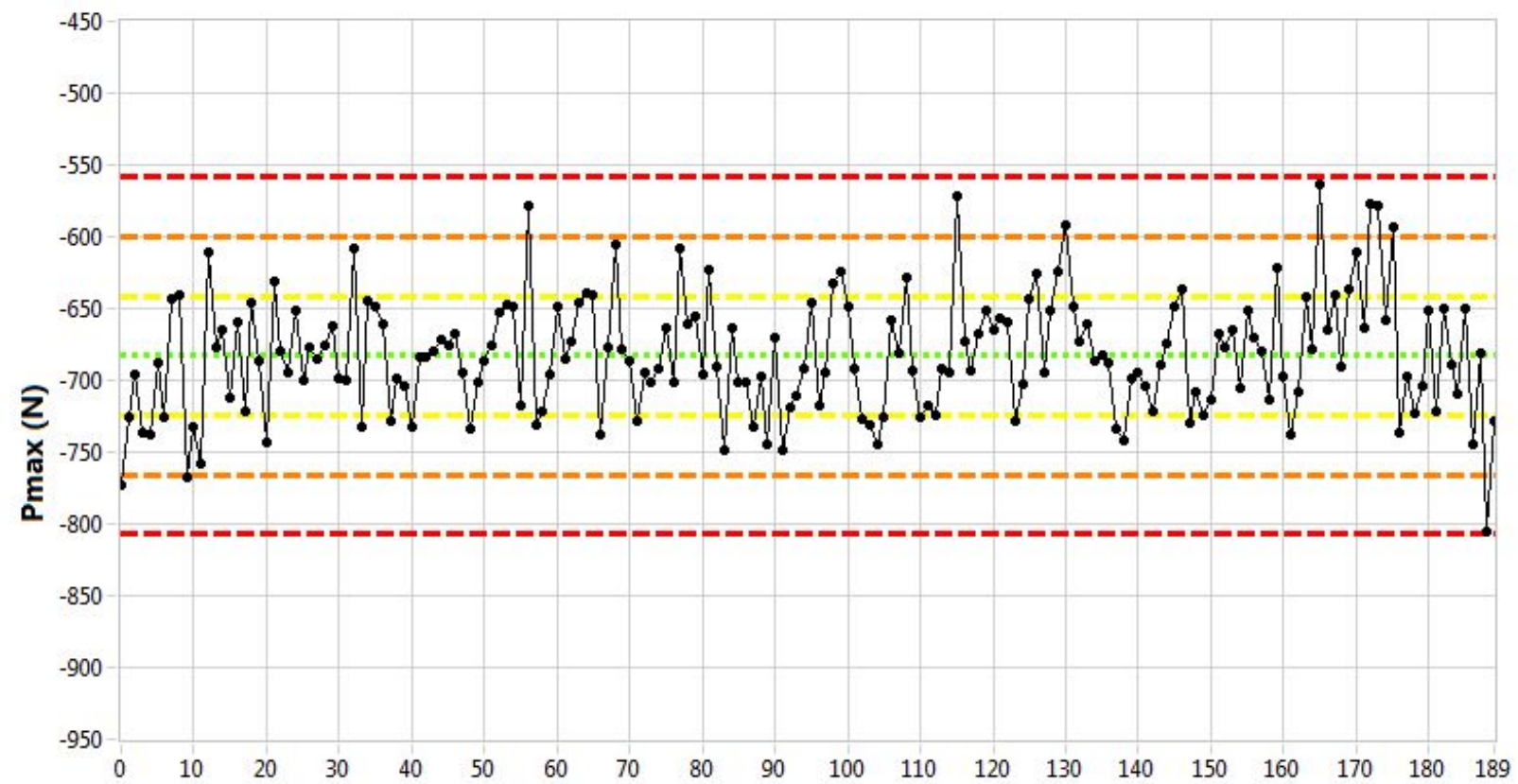

Figure 17. Max load $(\mathrm{N})$, mean $=-682.7$, standard deviation $=41.43$. 
TEM-10200-1

$12 / 19 / 17$

Rev. 08

Title: $\quad$ Baseline Characterization Database Verification Report - 2114 Billet A20570

ECAR No.: 4322

Rev. No.: $0 \quad$ Project No.: 32138

Date: $12 / 02 / 2019$

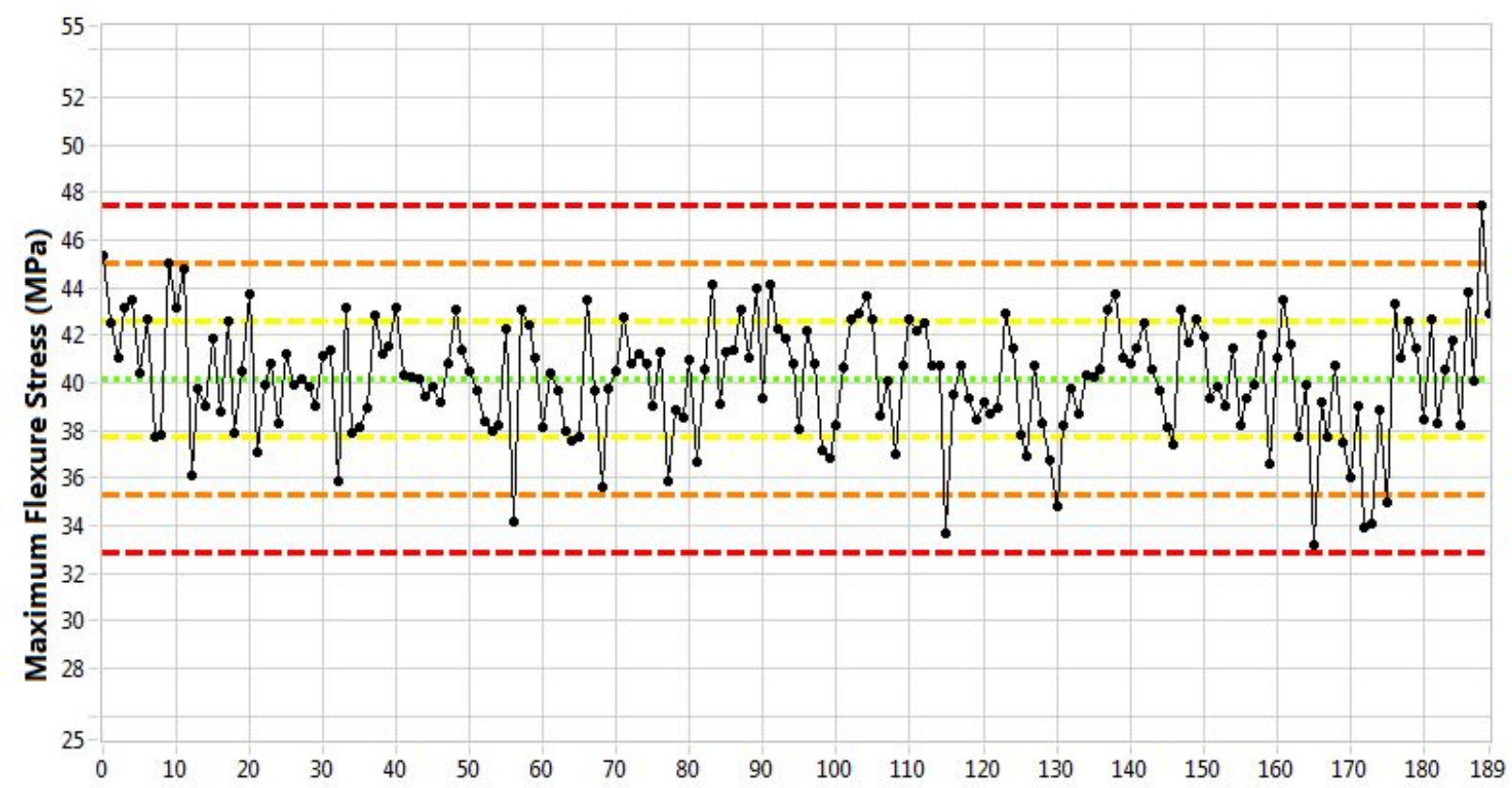

Figure 18. Maximum flexure stress $(\mathrm{MPa})$, mean $=40.2$, standard deviation $=2.44$.

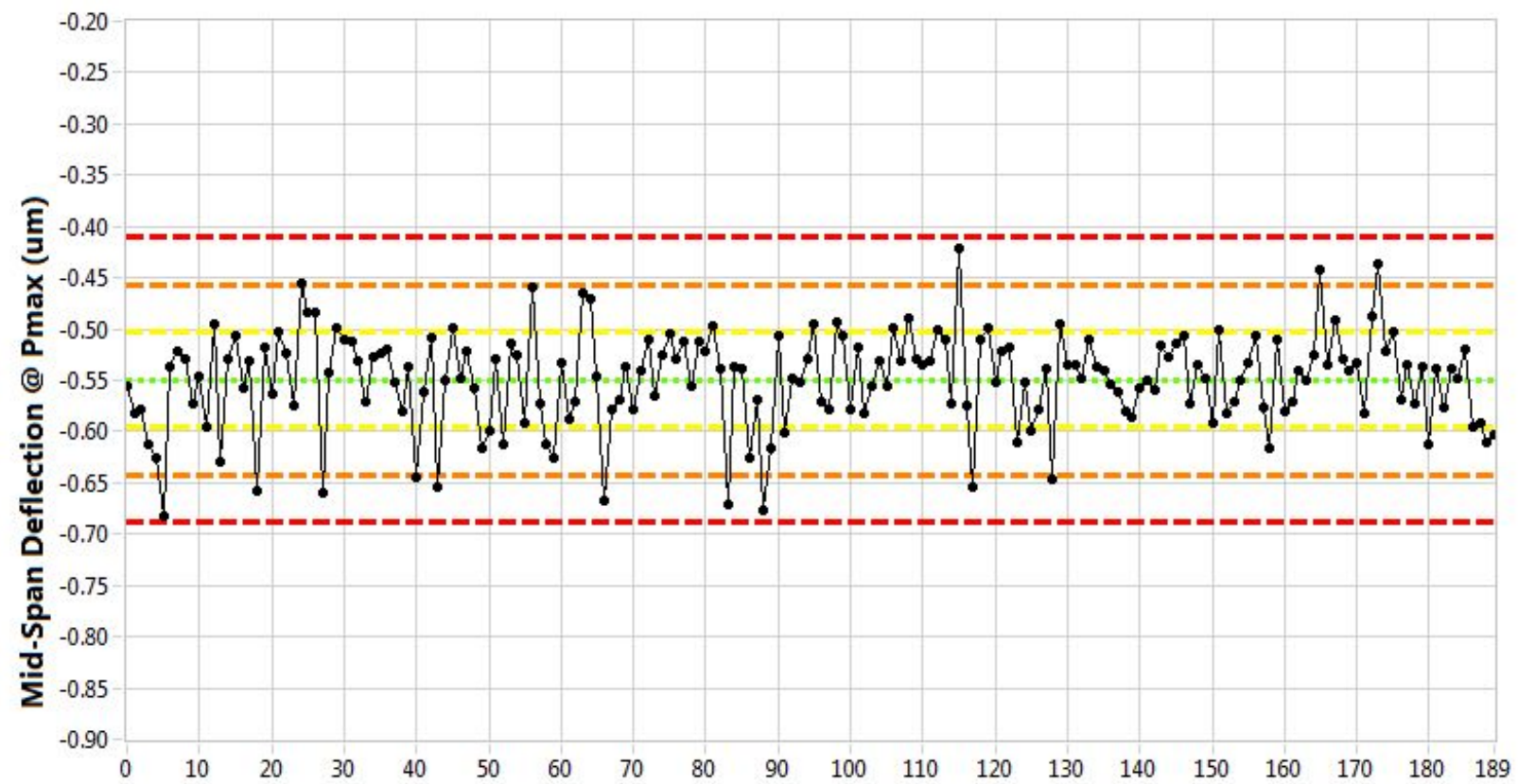

Figure 19. Mid-span deflection @ $\max$ load (um), mean = -0.5493, standard deviation $=0.0465$. 
TEM-10200-1

$12 / 19 / 17$

Rev. 08

ENGINEERING CALCULATIONS AND ANALYSIS

Title: $\quad$ Baseline Characterization Database Verification Report - 2114 Billet A20570

ECAR No.: 4322

Rev. No.: 0

Project No.:

32138

Date: $12 / 02 / 2019$

\section{Density Values}

Similar to the compression specimens, the flexural specimens' geometry facilitated an opportunity to measure density. Figure 20 shows density from the flexural specimens. All flexural specimens' data and associated deviations compare well with the compression specimens' density data.

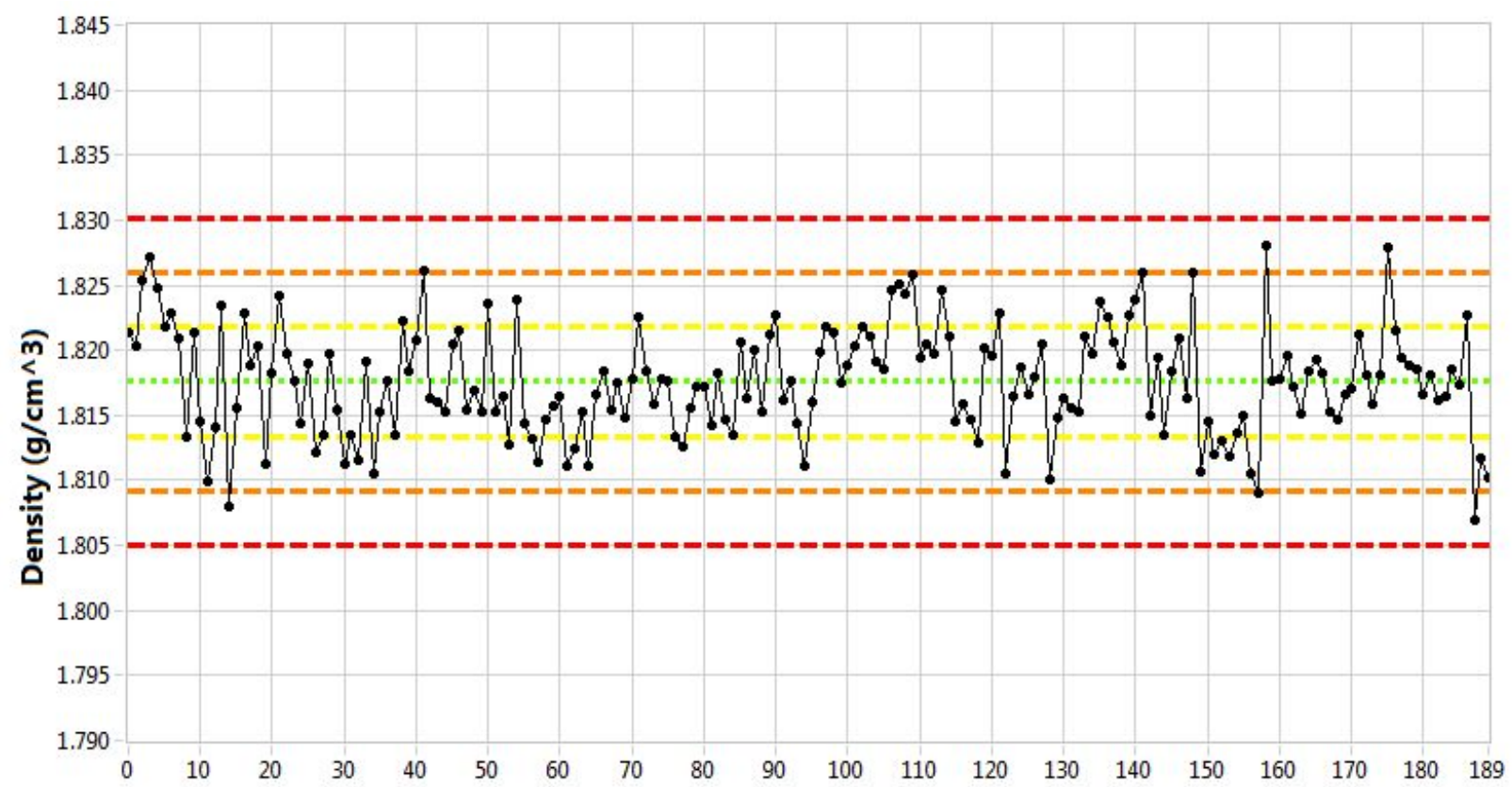

Figure 20. Density $\left(\mathrm{g} / \mathrm{cm}^{\wedge} 3\right)$, mean $=1.8176$, standard deviation $=0.0042$.

\section{Fundamental Frequency}

The precise parallelepiped geometry of flexural specimens renders them particularly valuable for accurate measurements of fundamental frequency to collect elastic constants for both dynamic Young's

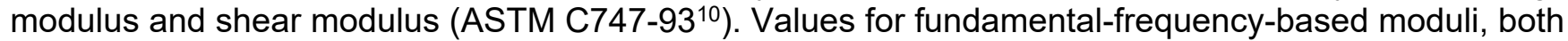
in flexural and torsional modes (shown in Figure 21 and Figure 22), are calculated from the equations provided in ASTM C1259-08. ${ }^{11}$ These data all fell within \pm 3 standard deviations from their respective means. 
TEM-10200-1

$12 / 19 / 17$

Rev. 08

Title: $\quad$ Baseline Characterization Database Verification Report - 2114 Billet A20570

ECAR No.: 4322

Rev. No.: $0 \quad$ Project No.: 32138

Date: $12 / 02 / 2019$

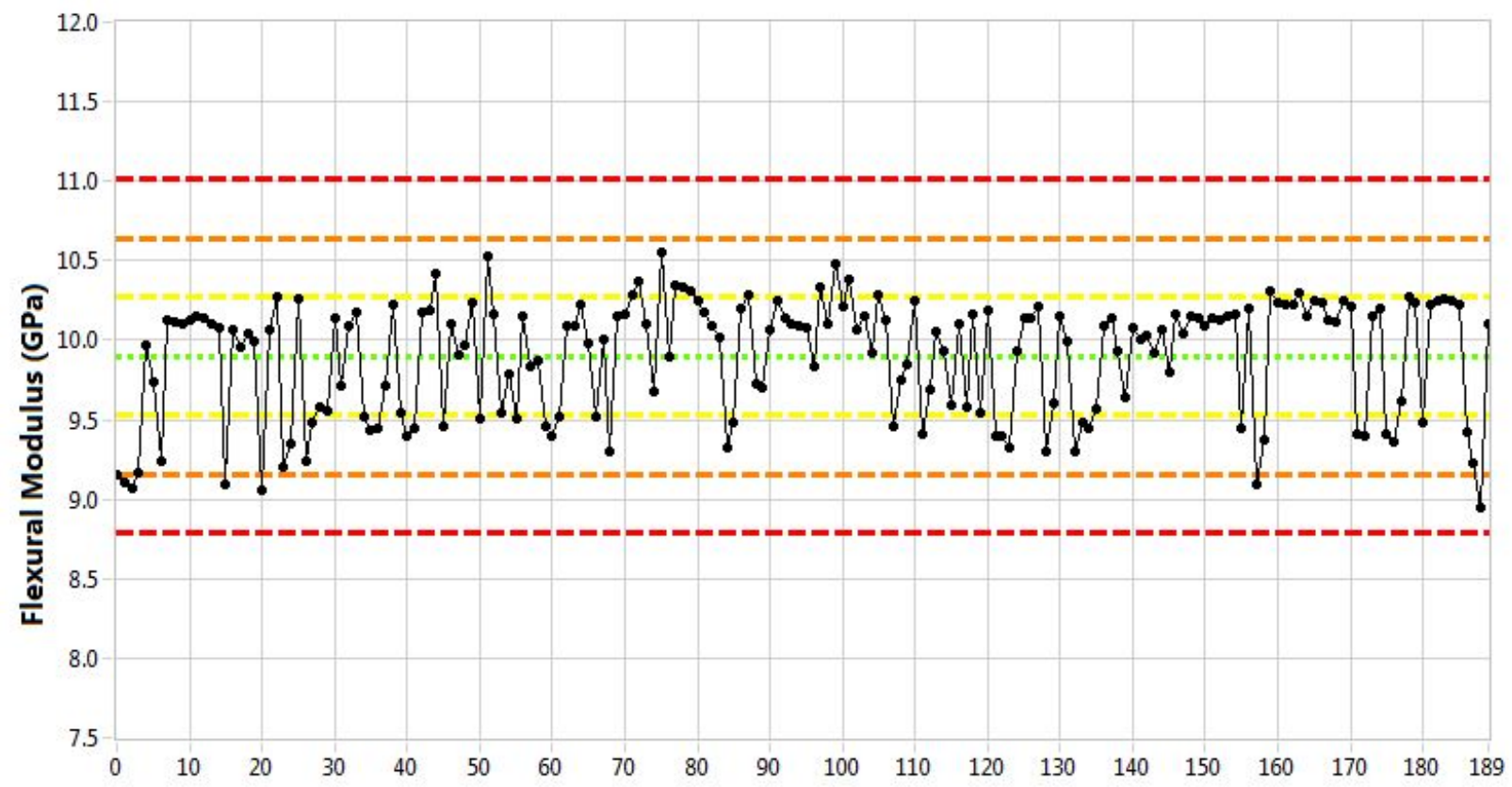

Figure 21. Flexural vibration-mode modulus $(\mathrm{GPa})$, mean $=9.9$, standard deviation $=0.37$.

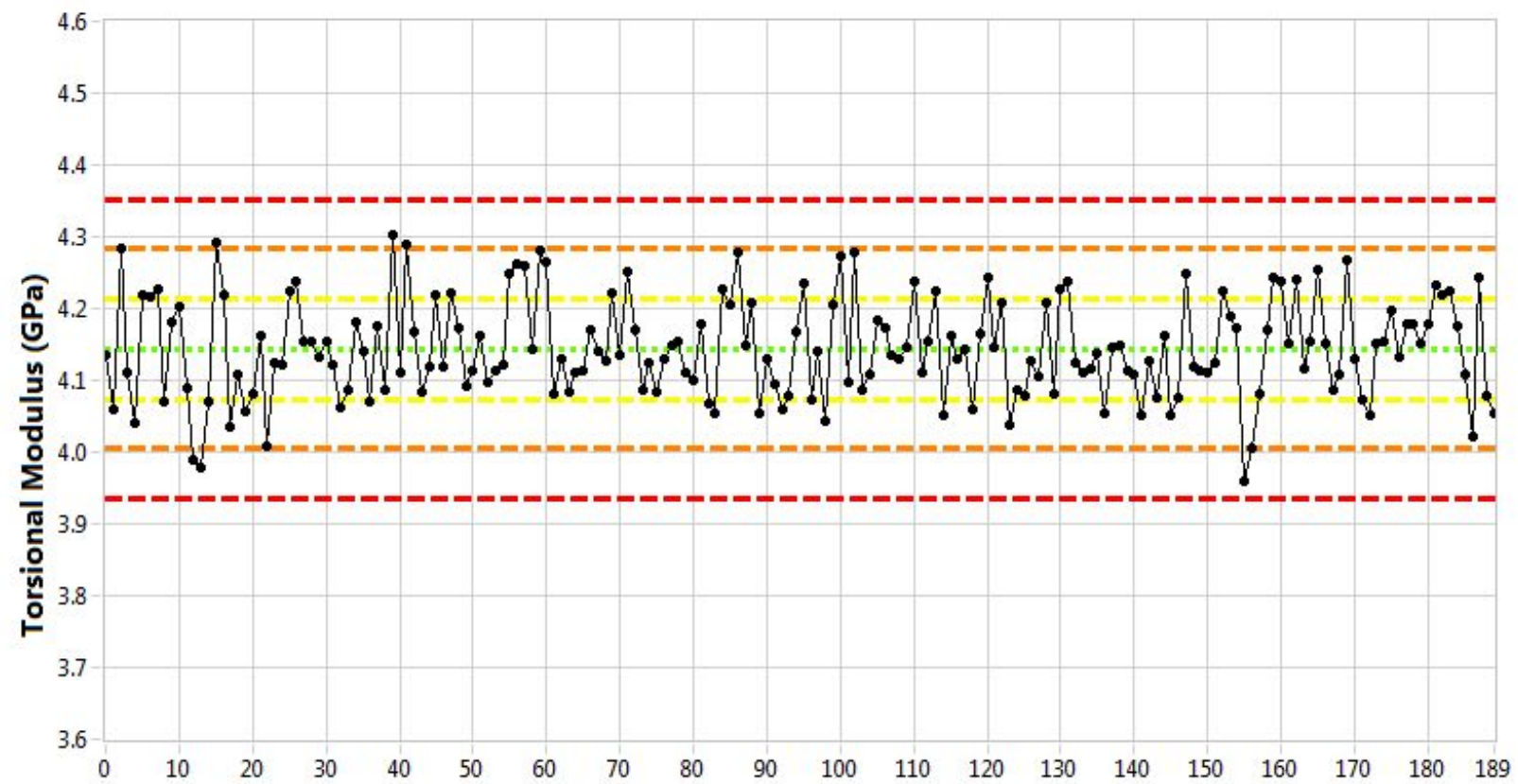

Figure 22. Torsional vibration-mode modulus $(\mathrm{GPa})$, mean $=4.1$, standard deviation $=0.07$. 
TEM-10200-1

$12 / 19 / 17$

Rev. 08

ENGINEERING CALCULATIONS AND ANALYSIS

Page 21 of 28

Title: $\quad$ Baseline Characterization Database Verification Report - 2114 Billet A20570

$\begin{array}{lllll}\text { ECAR No.: } 4322 & \text { Rev. No.: } 0 & \text { Project No.: } 32138 \quad \text { Date: } 12 / 02 / 2019\end{array}$

Tensile Specimen Database (2114 A20570T)

\section{Tensile Testing}

Tensile testing was performed per ASTM C749-08. ${ }^{16}$ Data verification follows the principles discussed in previous sections. As with other specimen types, data verification lies not only in documented adherence to applicable test plans and standards, but in noted correlations between recorded test properties and analyses for outlying values. Additional verification of test conditions can be carried out through an analysis of ancillary physical characteristics.

Initially, the tensile specimens were machined with nominal gauge diameters of 0.375 inches (9.525 $\mathrm{mm})$. When tested under tension with these dimensions, only three out of the first 17 specimens failed within the gauge section. To avoid this, the gauge diameters were reduced to 3.45 inches $(8.763 \mathrm{~mm})$. This decreased the out-of-gauge section failures to less than $3 \%$. After the reduction in gauge diameter, there were 161 tensile specimens. Figure 23 shows the gauge diameters of these tensile specimens.

Figure 24 and Figure 25 show the relationship between tensile load and recorded tensile strength for all of the specimens tested in uniaxial tension from the 2114 Billet A20570. Figure 26 shows the recorded tensile stress for the tested specimens. Further comparisons and verification can be made with extensometer-based measured strain (shown in Figure 27), which will reflect an additional correlation with stress values through material elastic constants. Comparing the extreme values again shows this relationship to be valid. Figure 23-Figure 27 also show a few outliers. As with the compression-testing data, no supporting data warrant the removal of these data from the database.

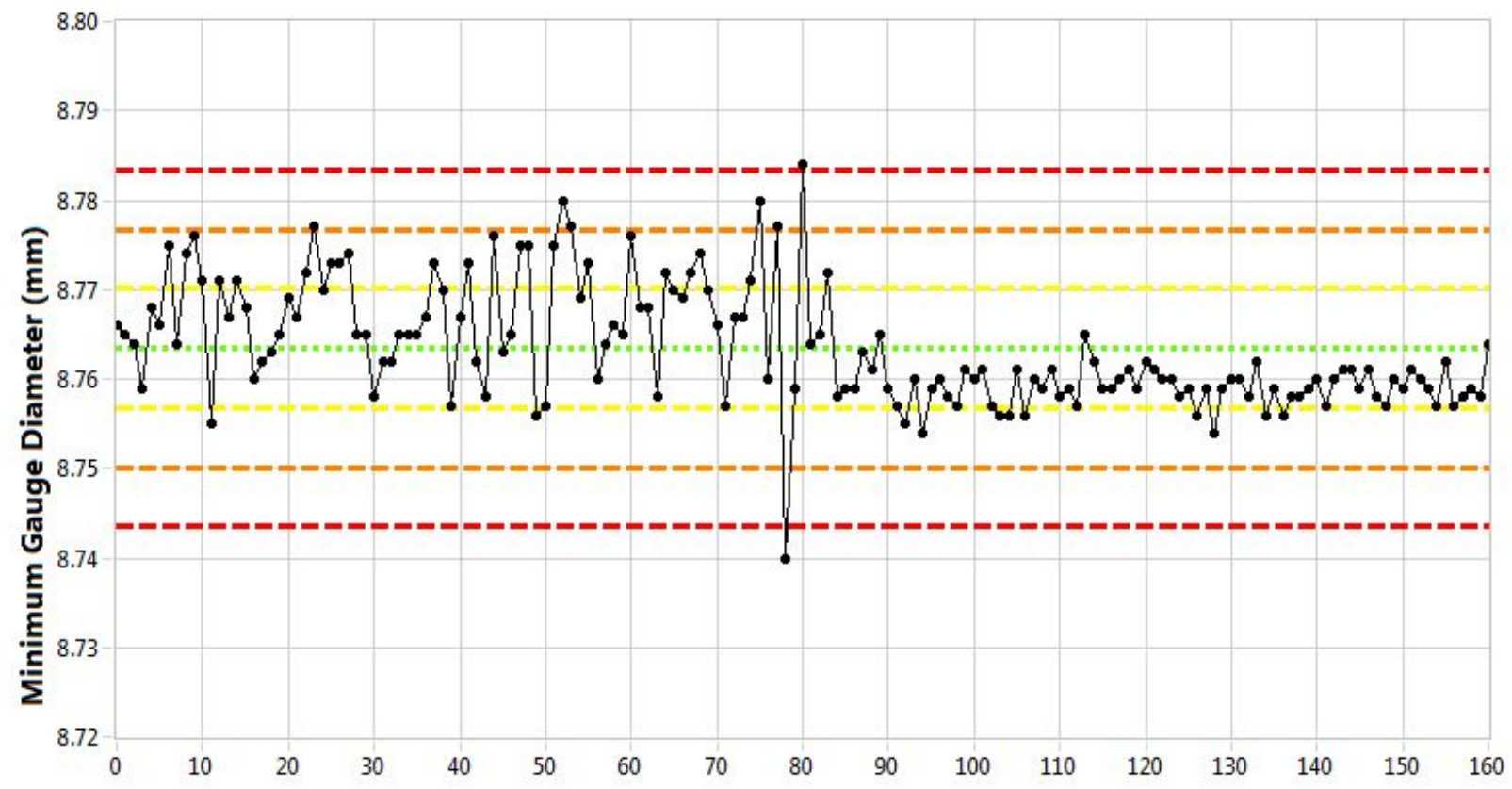

Figure 23. Minimum gauge diameter $(\mathrm{mm})$, mean $=8.7634$, standard deviation $=0.0067$. 
TEM-10200-1

$12 / 19 / 17$

Rev. 08

Title: $\quad$ Baseline Characterization Database Verification Report - 2114 Billet A20570

ECAR No.: 4322

Rev. No.: $0 \quad$ Project No.: 32138

Date: $12 / 02 / 2019$

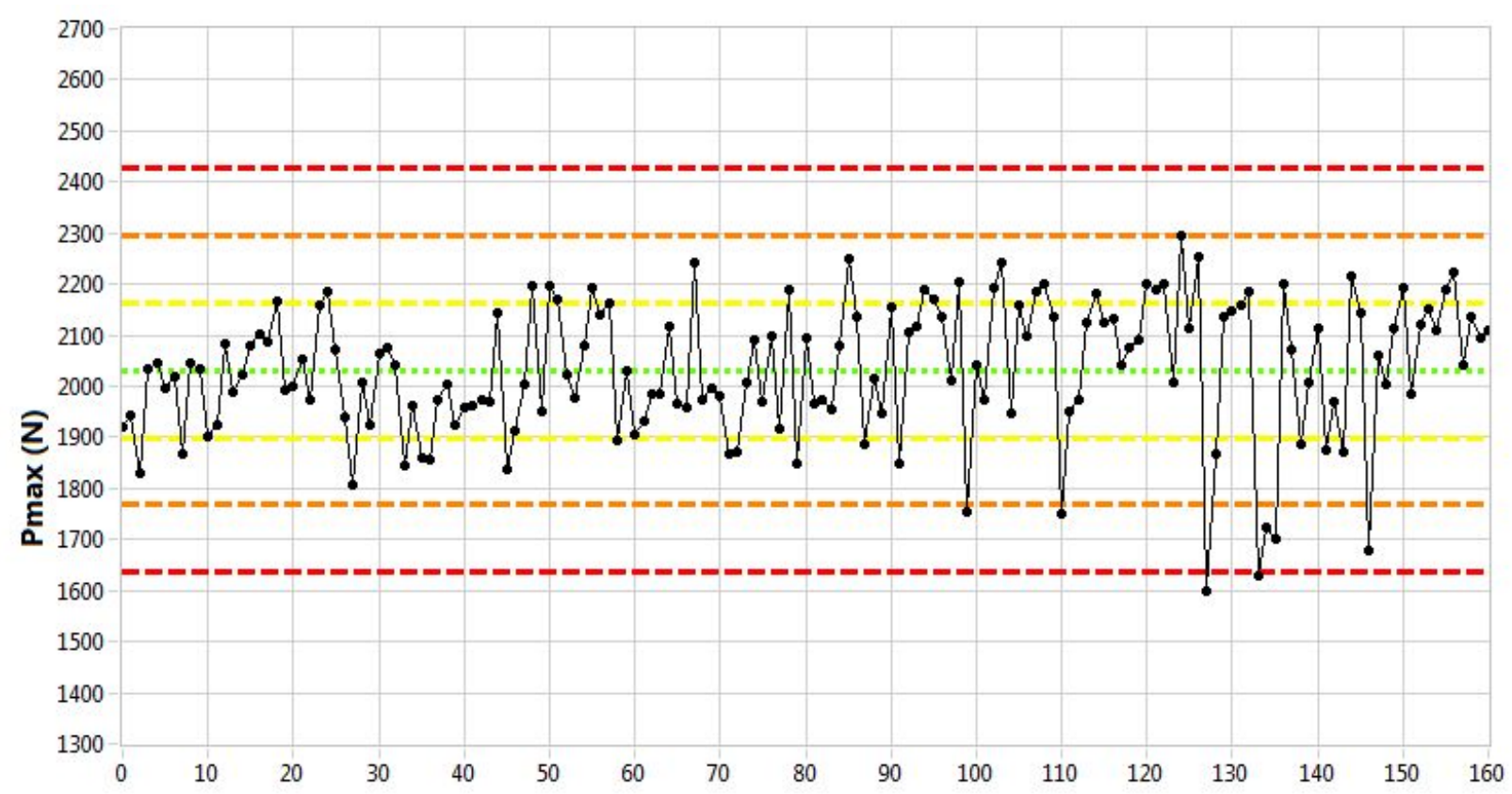

Figure 24. $\operatorname{Max}$ load $(\mathrm{N})$, mean $=2031.7$, standard deviation $=132.07$.

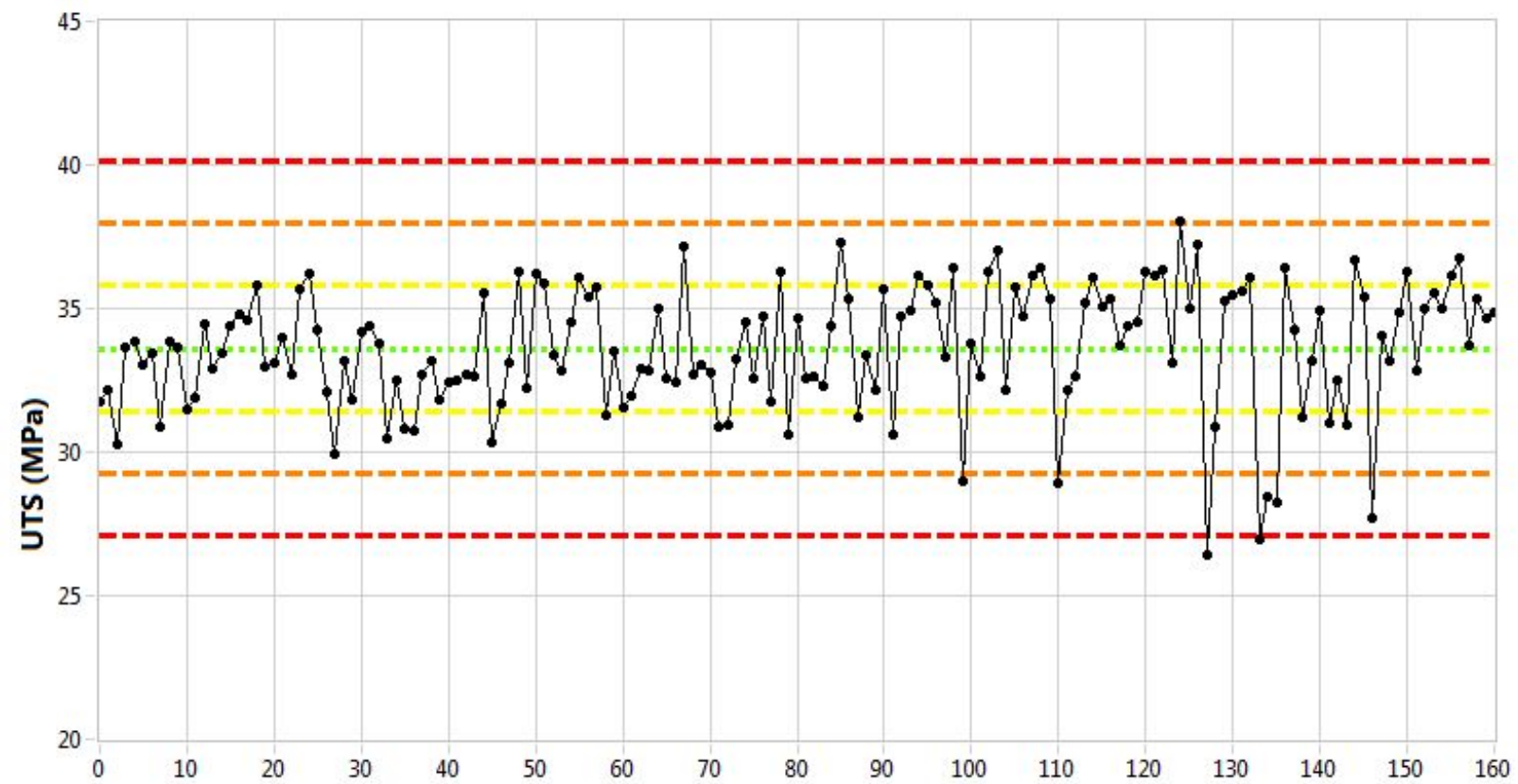

Figure 25. Ultimate tensile strength $(\mathrm{MPa})$, mean $=33.6$, standard deviation $=2.18$. 
TEM-10200-1

$12 / 19 / 17$

Rev. 08

Title: $\quad$ Baseline Characterization Database Verification Report - 2114 Billet A20570

ECAR No.: 4322

Rev. No.: $0 \quad$ Project No.: 32138

Date: $12 / 02 / 2019$

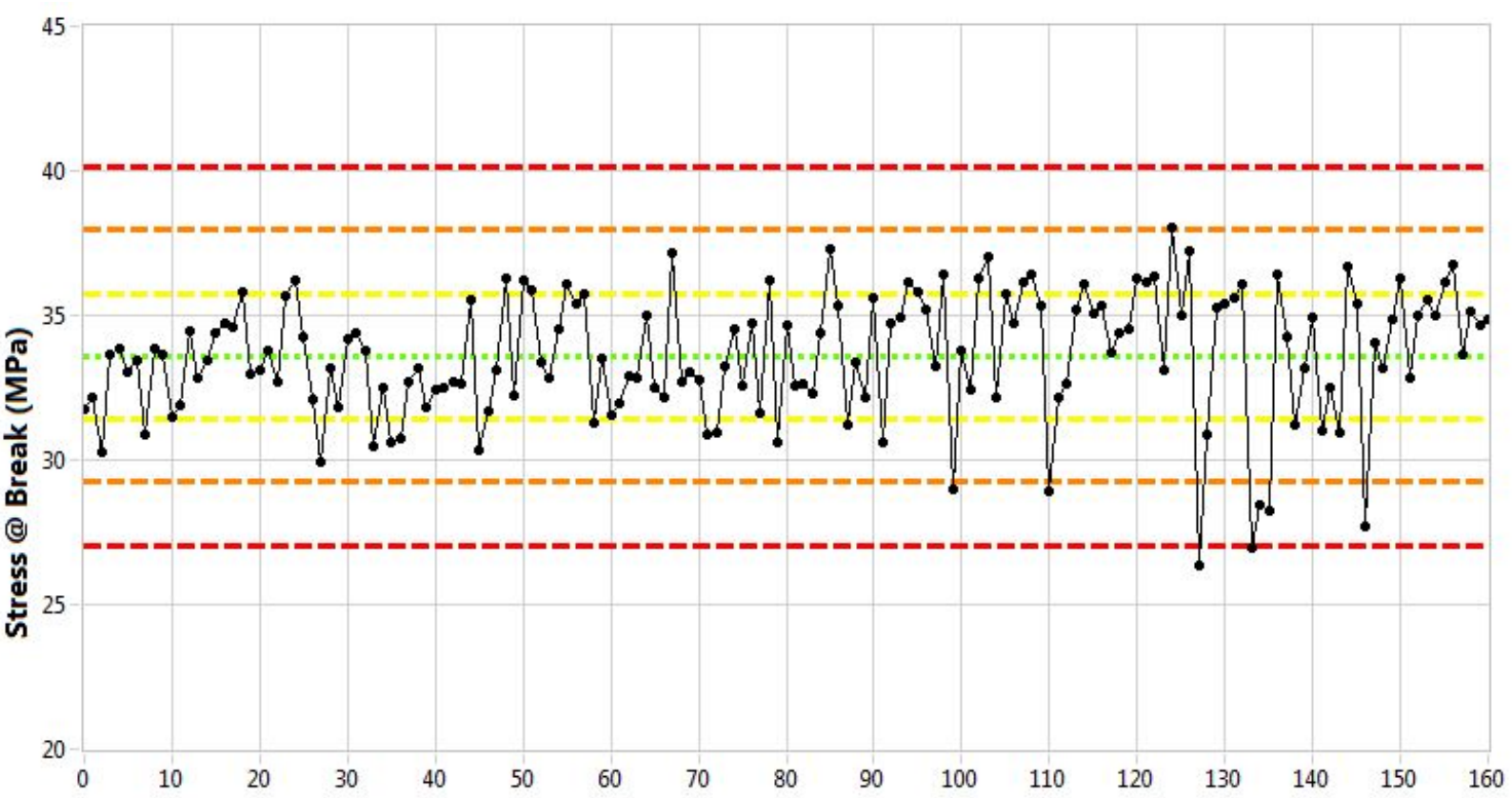

Figure 26. Stress at break $(\mathrm{MPa})$, mean $=33.6$, standard deviation $=2.18$.

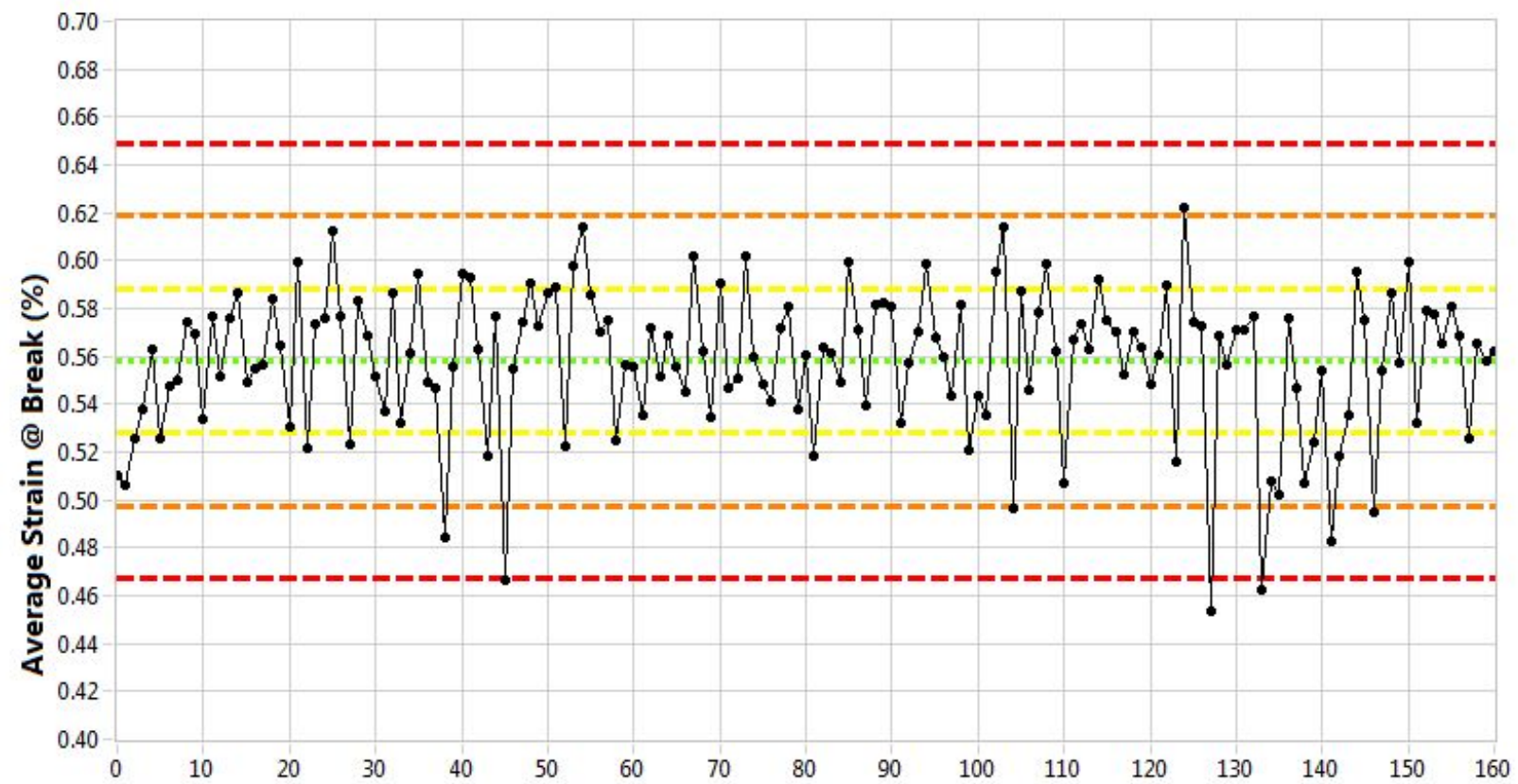

Figure 27. Average strain at break $(\%)$, mean $=0.5581$, standard deviation $=0.0303$. 
Rev. 08

Title: $\quad$ Baseline Characterization Database Verification Report - 2114 Billet A20570

$\begin{array}{lllll}\text { ECAR No.: } 4322 & \text { Rev. No.: } 0 & \text { Project No.: } 32138 \quad \text { Date: } 12 / 02 / 2019\end{array}$

\section{REMACHINED SPECIMEN PROPERTIES}

Two of the key components to direct comparisons between baseline and AGC data are (1) the analyses of specimens with similar geometries and (2) employment of similar test techniques for comprehensive validation. The geometry of the tensile specimens provides the opportunity to "remachine" the unstressed sections of the specimen ends (shown in Figure 28) to the same dimensions as AGC piggyback specimens. A random cross-section of tensile specimens was remachined in order to repeat tests on AGC-sized specimens (i.e., diffusivity and split disc testing). Using actual test specimens for remachining allows continued use of the specimen-identification and tracking-code system because specimens are machined from tracked locations and can reuse the identification code.

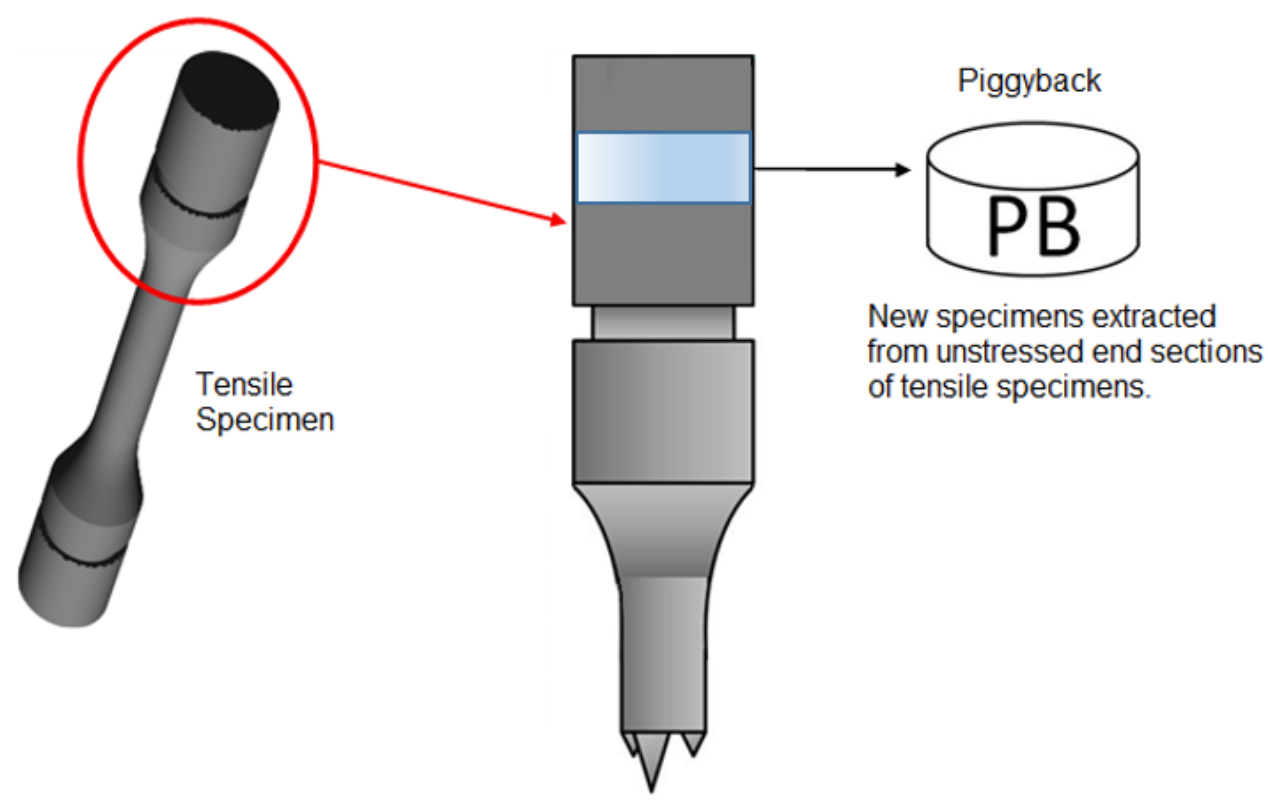

Figure 28. Unstressed specimen remnants from tensile specimens are remachined into AGC-sized piggyback specimens.

\section{REMACHINED SPLIT DISC TESTING}

Split disc tensile-strength testing was performed in accordance with PLN-3348 ${ }^{2}$, Revision 4, Subsection 6.1.1.5. This allows for a direct comparison of tensile data to data that were acquired through strict application of ASTM C749-08 ${ }^{16}$. Figure 29 and Figure 30 show strength and load data from the split disc testing. The mean strength value calculated from split disc testing was approximately $20 \%$ lower than that from traditional tensile testing (Figure 25) and had a 50\% lower standard deviation. 
TEM-10200-1

$12 / 19 / 17$

Rev. 08

Title: $\quad$ Baseline Characterization Database Verification Report - 2114 Billet A20570

ECAR No.: 4322

Rev. No.: $0 \quad$ Project No.: 32138

Date: $12 / 02 / 2019$

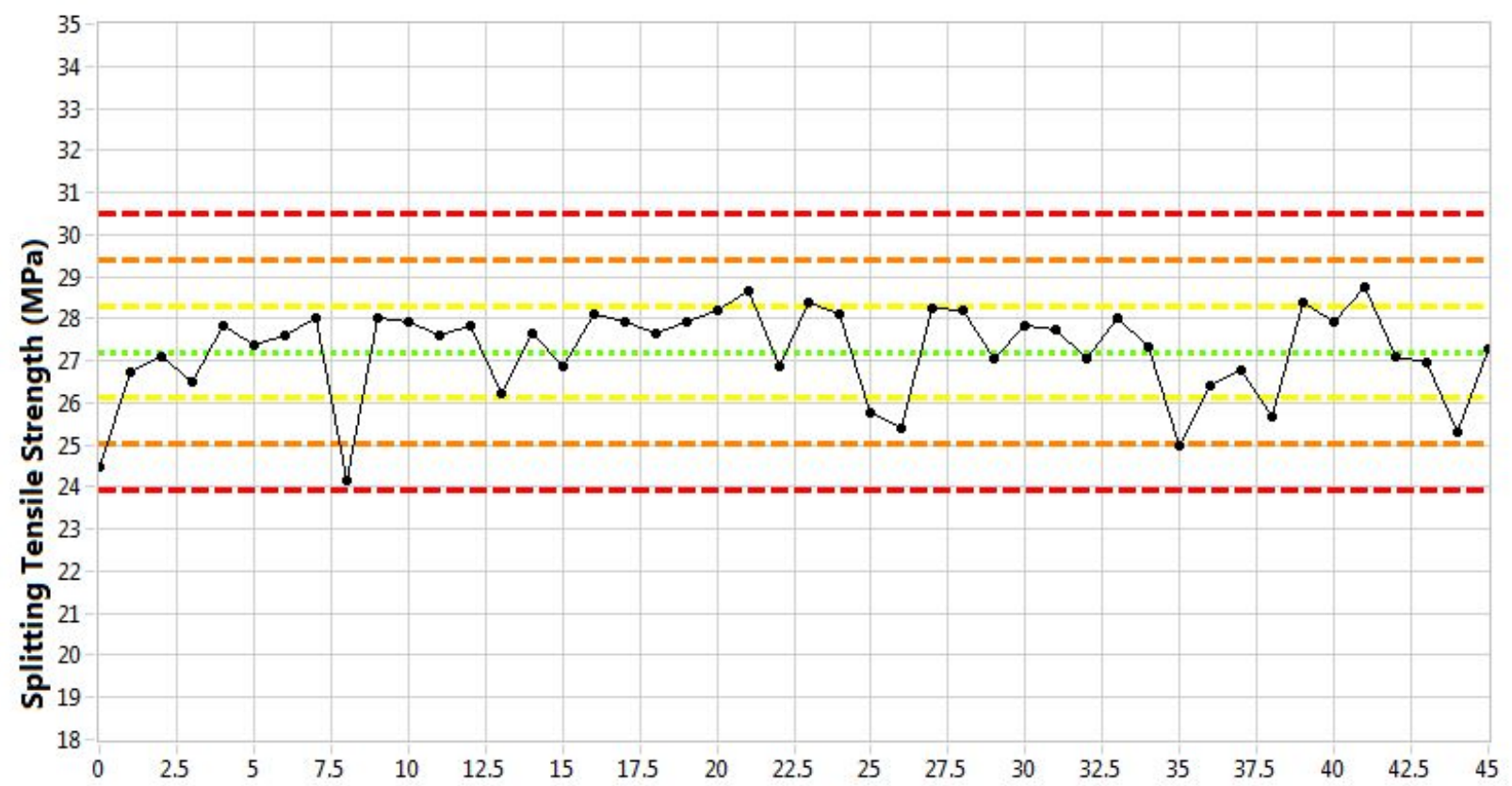

Figure 29. Split Disc tensile strength $(\mathrm{MPa})$, mean $=27.21$, standard deviation $=1.09$.

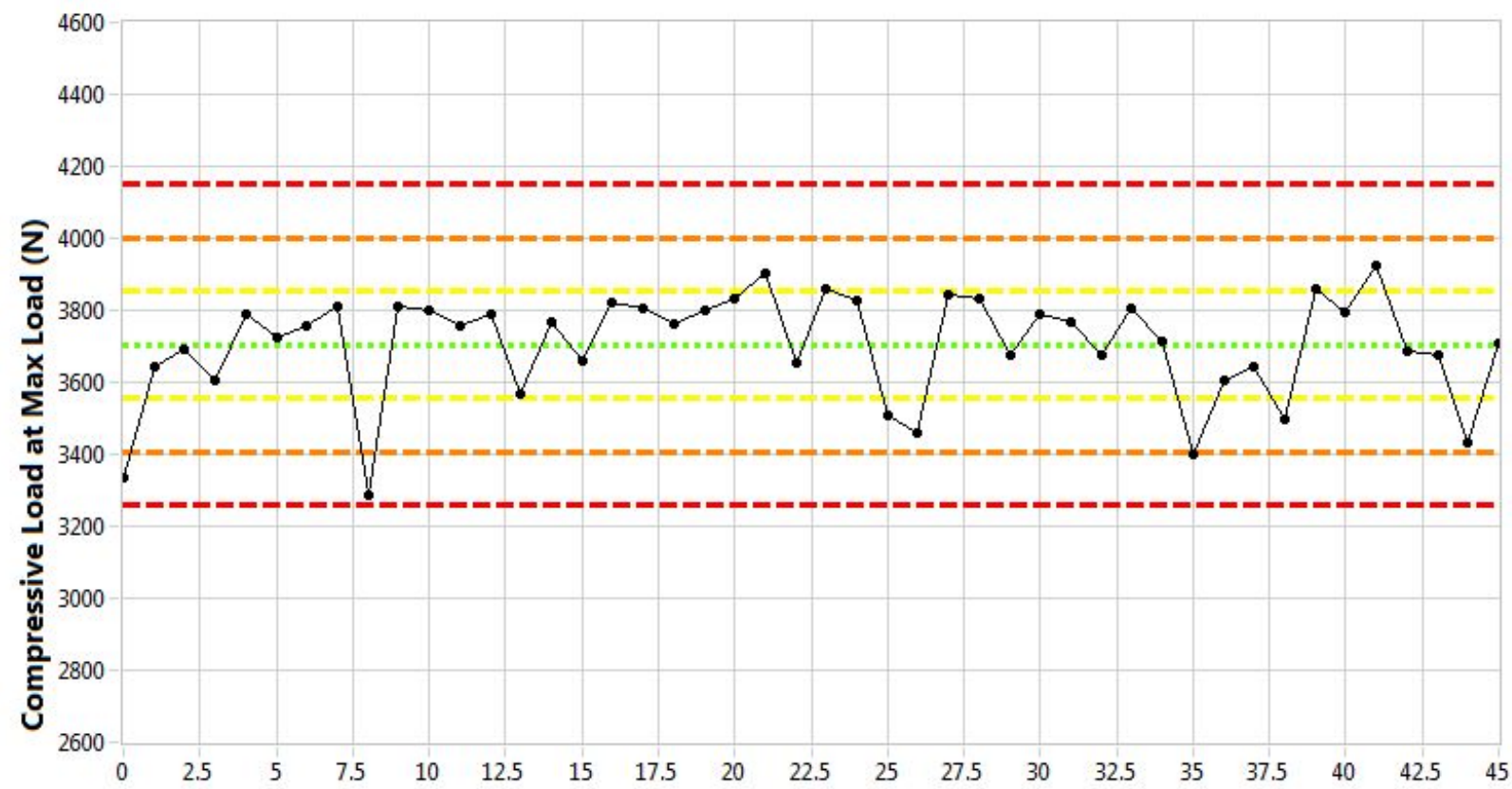

Figure 30. Split Disc compressive load at $\max$ load $(\mathrm{N})$, mean $=3703.6$, standard deviation $=148.7$. 
Rev. 08

Title: $\quad$ Baseline Characterization Database Verification Report - 2114 Billet A20570

$\begin{array}{lllll}\text { ECAR No.: } 4322 & \text { Rev. No.: } 0 & \text { Project No.: } 32138 \quad \text { Date: } 12 / 02 / 2019\end{array}$

\section{REMACHINED SPECIMEN DIFFUSIVITY}

Thermal-diffusivity values are collected from remachined tensile specimens per ASTM E1461-07. ${ }^{17}$ Diffusion of heat through the specimen following application of thermal energy via a laser source demonstrates heat-transfer characteristics and can be used to calculate thermal conductivity for design purposes. The resulting group of diffusivity values, revealing a tight grouping of thermal-transfer characteristics, is shown in Figure 31.

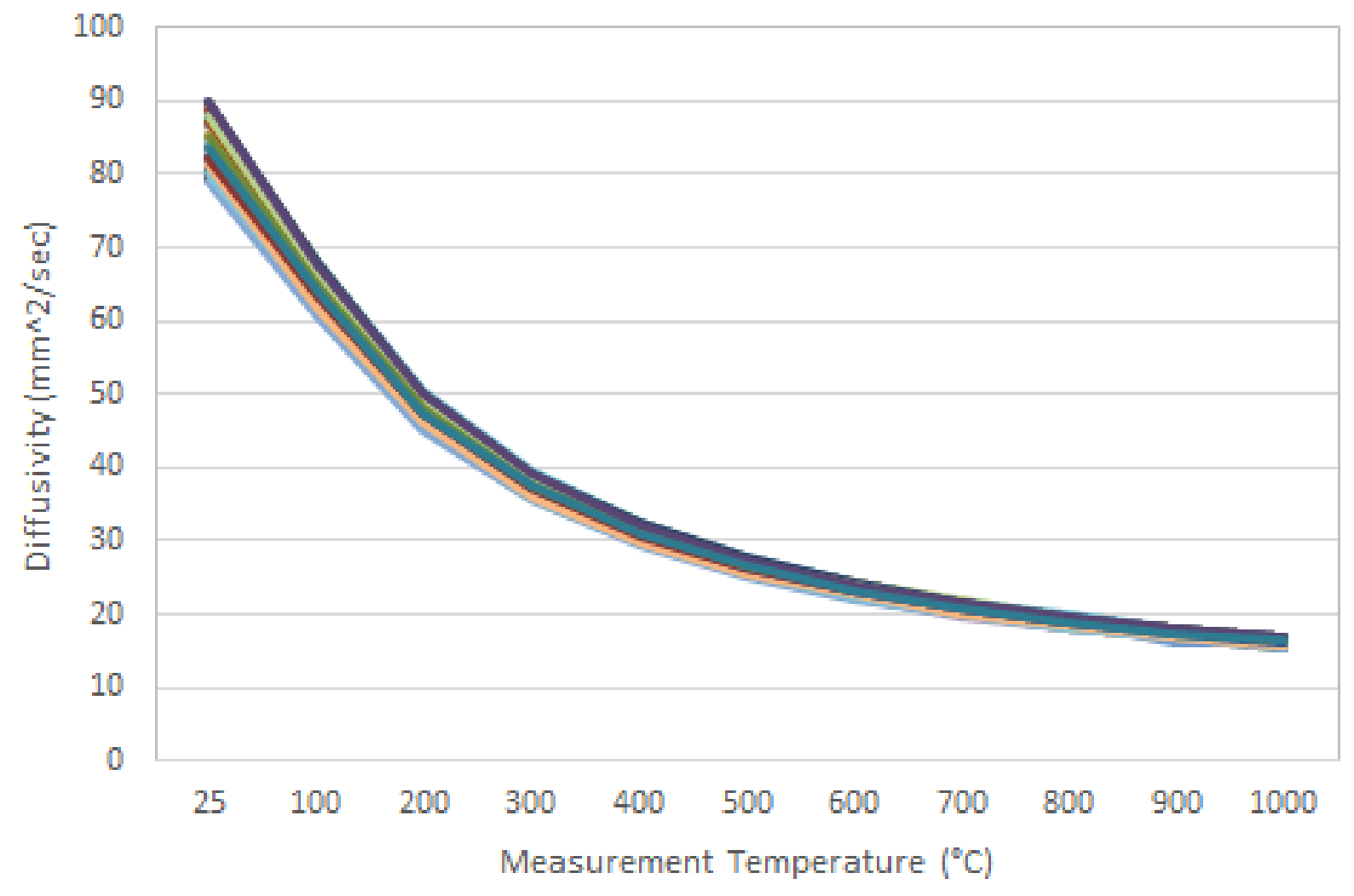

Figure 31. Remachined specimen diffusivity.

\section{SUMMARY}

Comprehensive data sets for 2114 Billet A20570 have been compiled into summary files of property scalar values. The data spreadsheet files are divided by mechanical test-specimen type into three main sets: (1) compressive, (2) flexural, and (3) tensile. The multitude of tests and evaluations performed on each specimen type are individually tabbed in the main data-set files.

In addition to a full visual review of the data files to determine whether obvious errors were made with the data collected (e.g., missing information or otherwise blank cells), graphical representations were made of individual evaluations to provide a means to spot anomalies. A review of the data indicates that the files, as submitted, are fully representative of the measured properties of the graphite billets being tested, as outlined in the applicable test procedures and program plans. 
Rev. 08

Title:

Baseline Characterization Database Verification Report - 2114 Billet A20570

ECAR No.: 4322

Rev. No.: 0

Project No:: 32138

Date: $12 / 02 / 2019$

\section{REFERENCES}

1. PLN-2497, “Graphite Technology Development Plan,” Rev. 1, October 4, 2010.

2. PLN-3348, “Graphite Mechanical Testing,” Rev. 4, March 16, 2017.

3. PLN-3467, "Baseline Graphite Characterization Plan: Electromechanical Testing," Rev. 2, June 22, 2015.

4. PLN-3267, “AGC-2 Characterization Plan,” Rev. 0, March 19, 2010.

5. Mark Carroll, Joe Lord, and David Rohrbaugh, +Baseline Graphite Characterization: First Billet, INL/EXT-10-19910, September 2010.

6. LWP-20000-01, "Conduct of Research Plan,” Rev. 0, August 2015

7. ASTM C695-15, "Standard Test Method for Compressive Strength of Carbon and Graphite," ASTM International, 2015.

8. $\quad$ ASTM D7972-14, "Standard Test Method for Flexural Strength of Manufactured Carbon and Graphite Articles Using Three-Point Loading at Room Temperature," ASTM International, 2014.

9. ASTM C769-09, "Standard Test Method for Sonic Velocity in Manufactured Carbon and Graphite Material for Use in Obtaining an Approximate Young's Modulus," ASTM International, 2009.

10. ASTM C747-93 (Reapproved 2005), "Standard Test Method for Moduli of Elasticity and Fundamental Frequencies of Carbon and Graphite Materials by Sonic Resonance," ASTM International, 2005.

11. ASTM C1259-08, "Standard Test Method for Dynamic Young's Modulus, Shear Modulus, and Poisson's Ratio for Advanced Ceramics by Impulse Excitation of Vibration," ASTM International, 2008.

12. ASTM C611-05, "Standard Test Method for Electrical Resistivity of Manufactured Carbon and Graphite Articles at Room Temperature," ASTM International, 2005.

13. ASTM E228-06, "Standard Test Method for Linear Thermal Expansion of Solid Materials with a Push Rod Dilatometer," ASTM International, 2006.

14. ASTM C559-90 (Reapproved 2005), "Standard Test Method for Bulk Density by Physical Measurements of Manufactured Carbon and Graphite Articles," ASTM International, 2005.

15. ASTM C651-91 (Reapproved 2005), "Standard Test Method for Flexural Strength of Manufactured Carbon and Graphite Articles Using Four-Point Loading at Room Temperature," ASTM International, 2005. 
TEM-10200-1

Rev. 08

Title: $\quad$ Baseline Characterization Database Verification Report - 2114 Billet A20570

ECAR No.: 4322

Rev. No.: $0 \quad$ Project No: 32138

Date: $12 / 02 / 2019$

16. ASTM C749-08, "Standard Test Method for Tensile Stress-Strain of Carbon and Graphite," ASTM International, 2008.

17. ASTM E1461-07, "Standard Test Method for Thermal Diffusivity by the Flash Method," ASTM International, 2007. 
TEM-10200-1

$03 / 01 / 2012$

ENGINEERING CALCULATIONS AND ANALYSIS

Page $A 1$ of $A 2$

Rev. 06

Title: $\quad$ Baseline Characterization Database Verification Report - 2114 Billet A20570

ECAR No.: 4322

Rev. No.: 0

Project No.: 32138

Date: $12 / 02 / 2019$

\section{Appendix A}

\section{Additional Compression Specimen Database Plots (2114 A20570)}

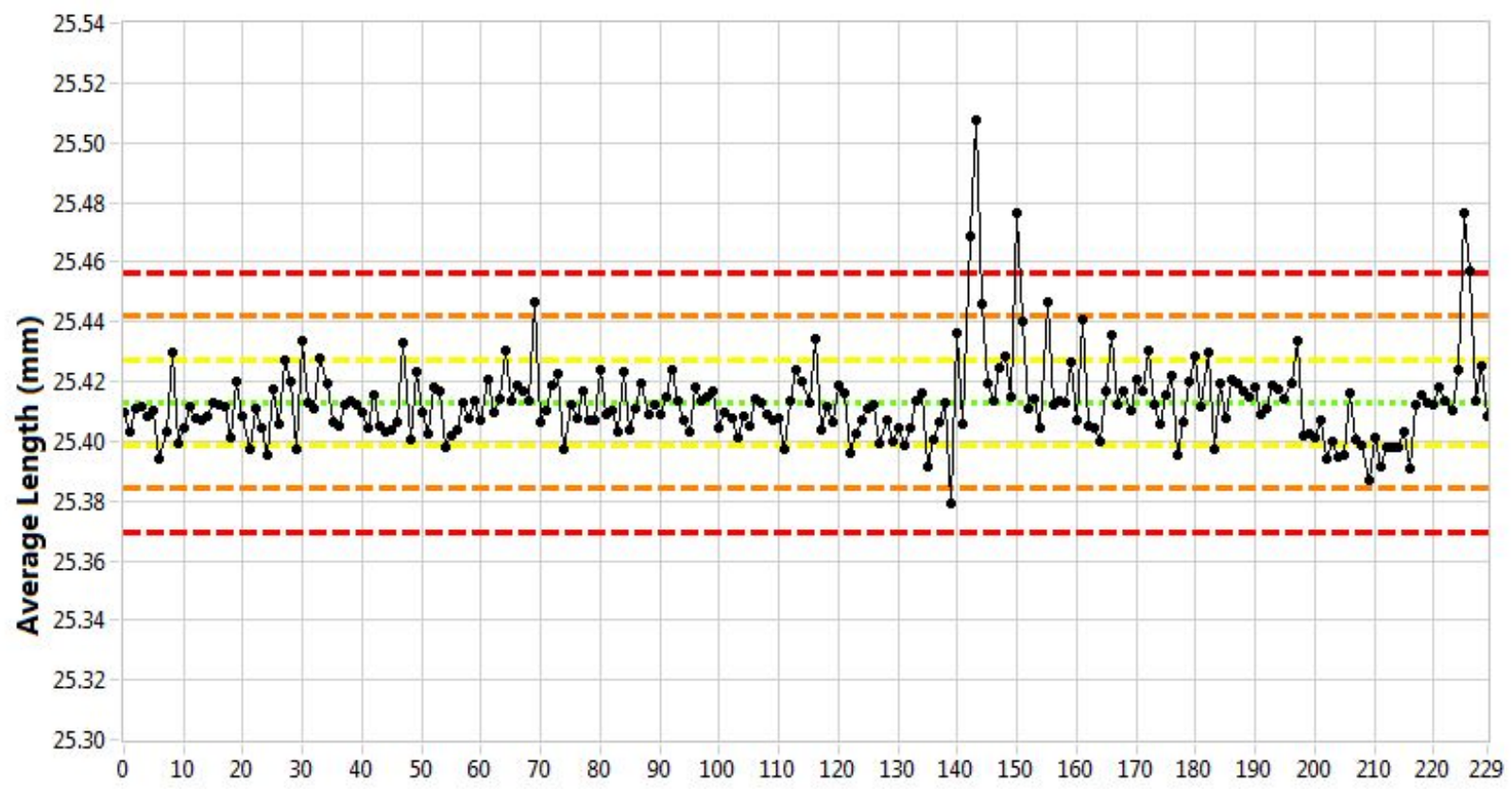

Figure A-1. Average length $(\mathrm{mm})$, mean $=25.4129$, standard deviation $=0.0144$.

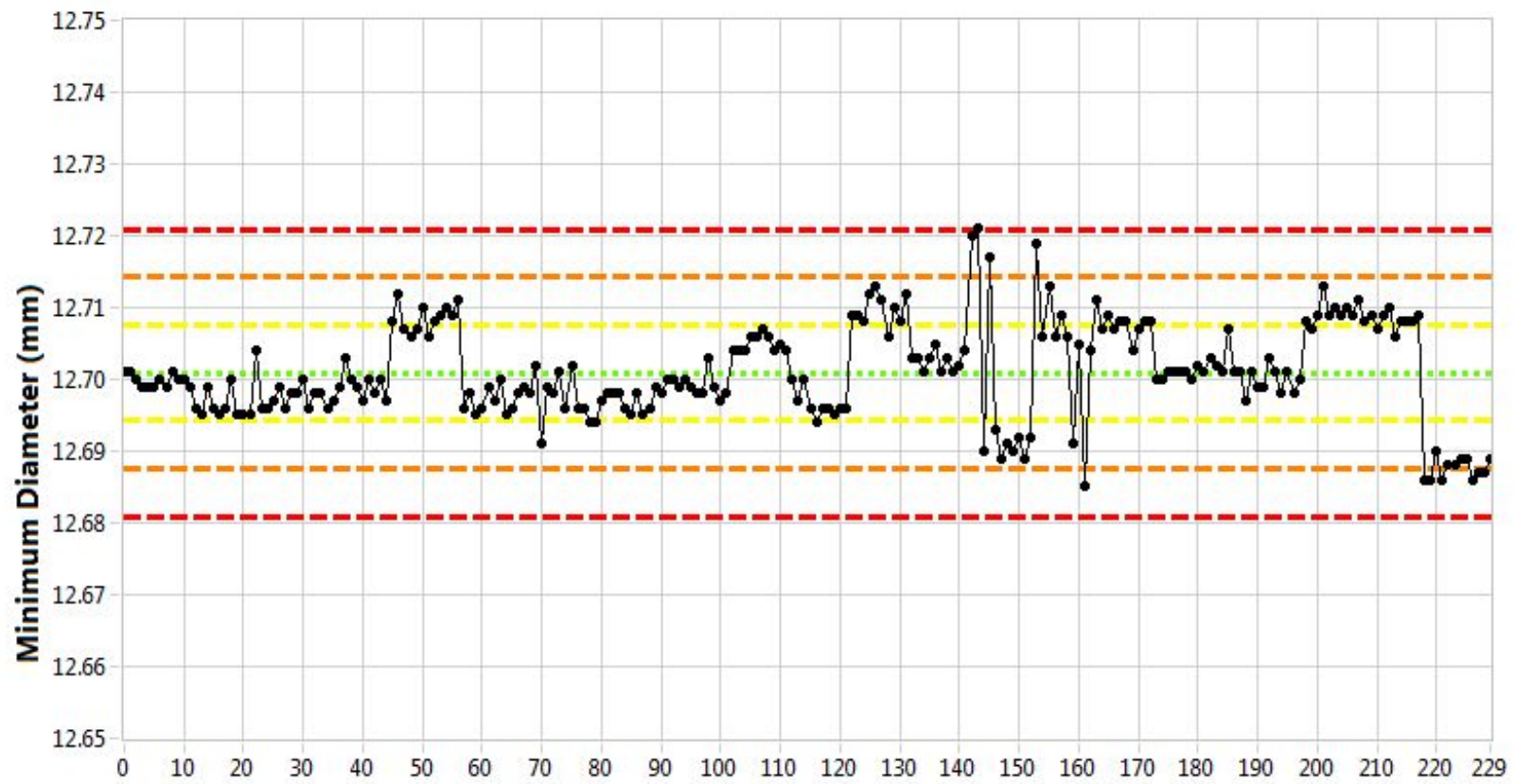

Figure A-2. Average diameter $(\mathrm{mm})$, mean $=12.7009$, standard deviation $=0.0067$. 
TEM-10200-1

$03 / 01 / 2012$

ENGINEERING CALCULATIONS AND ANALYSIS

Page $A 2$ of $A 2$

Rev. 06

Title: $\quad$ Baseline Characterization Database Verification Report - 2114 Billet A20570

ECAR No.: 4322

Rev. No.: $0 \quad$ Project No.: 32138

Date: $12 / 02 / 2019$

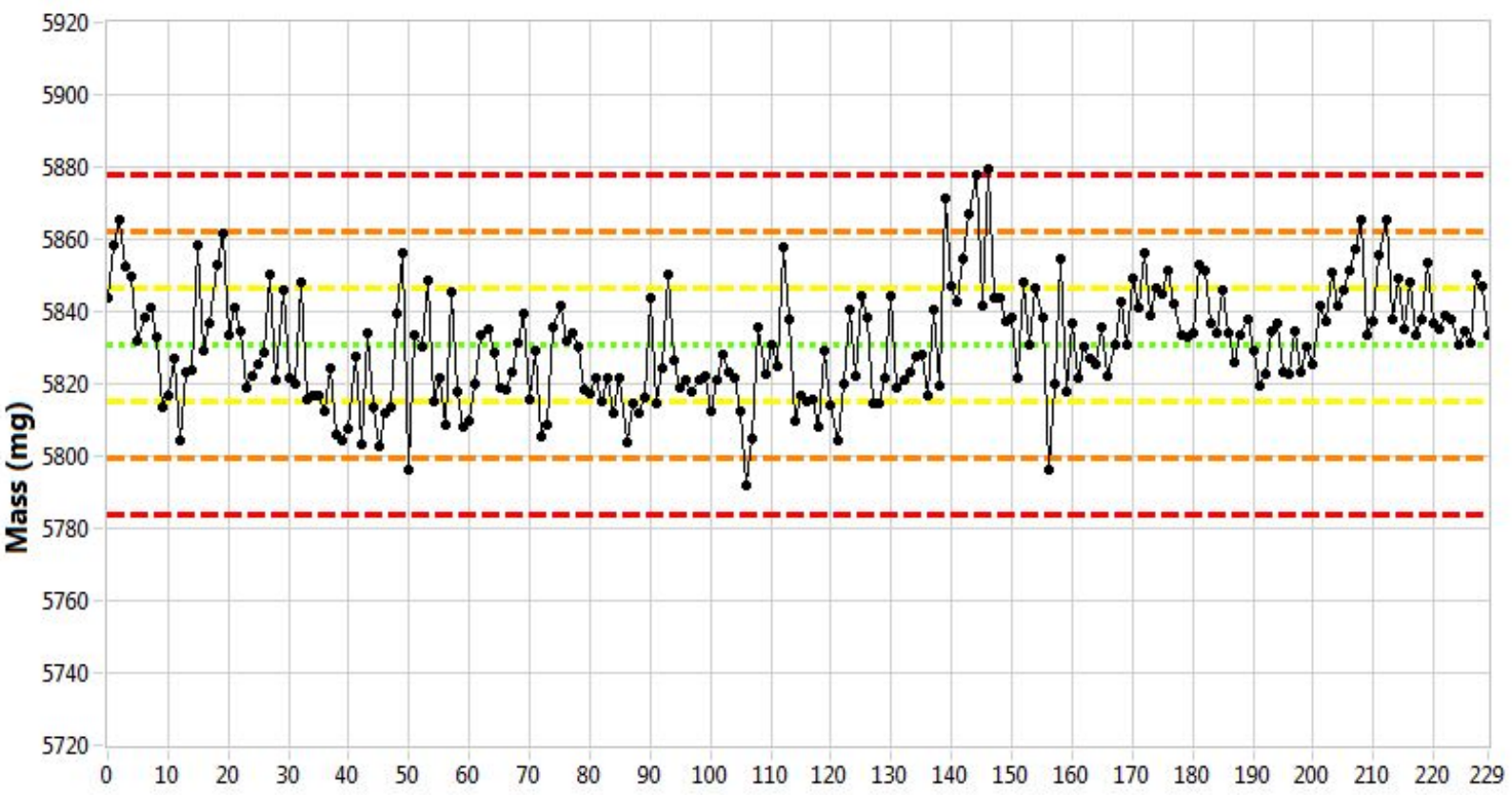

Figure A-3. Mass $(\mathrm{mg})$, mean $=5831.0$, standard deviation $=15.7$.

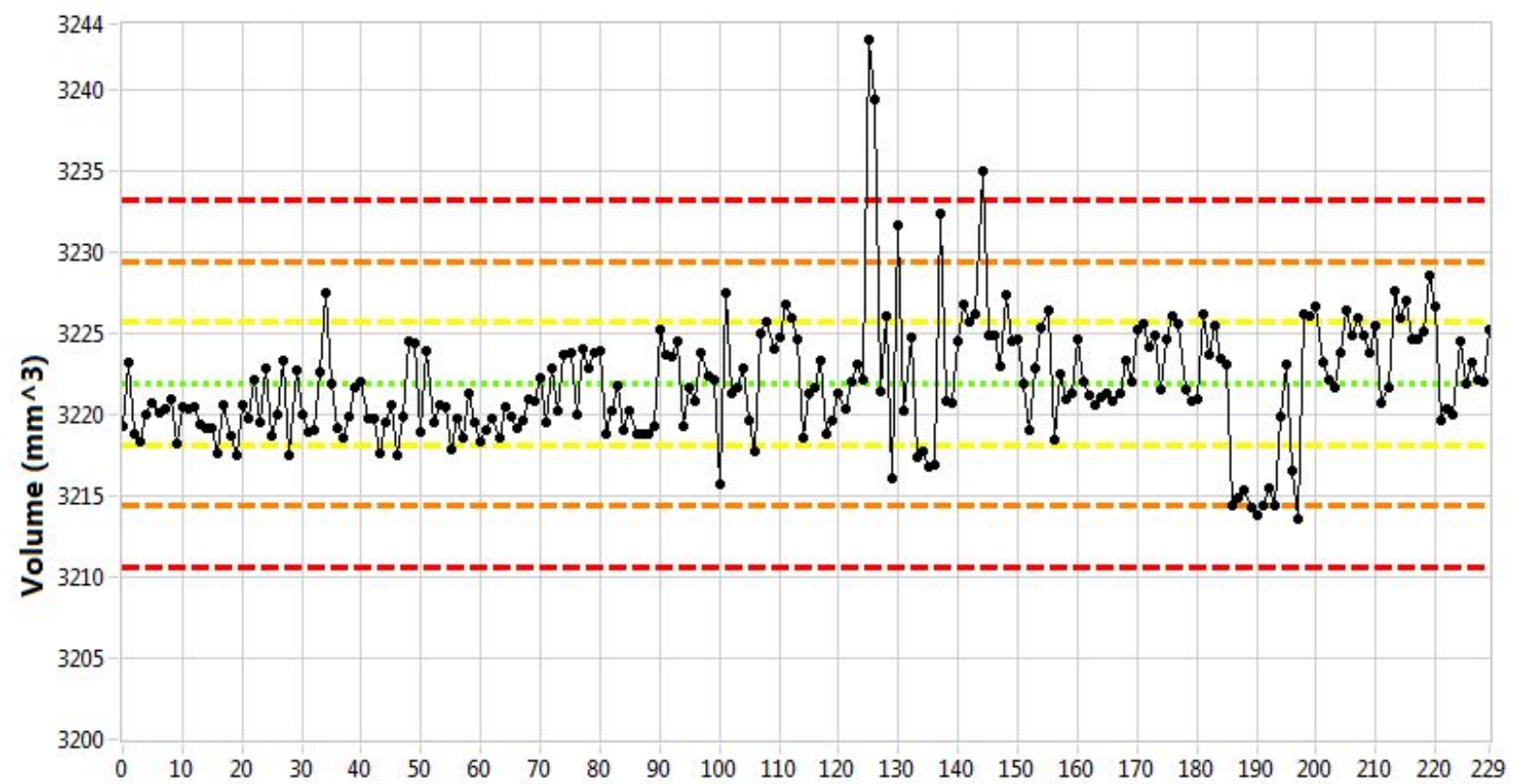

Figure A-4. Volume $\left(\mathrm{mm}^{\wedge} 3\right)$, mean $=3221.9$, standard deviation $=3.8$. 
TEM-10200-1

$03 / 01 / 2012$

ENGINEERING CALCULATIONS AND ANALYSIS

Page B1 of B2

Rev. 06

Title: $\quad$ Baseline Characterization Database Verification Report - 2114 Billet A20570

ECAR No.: 4322

Rev. No.: 0

Project No.: 32138

Date: $12 / 02 / 2019$

\section{Appendix B}

\section{Additional Flexural Specimen Database Plots (2114 A20570)}

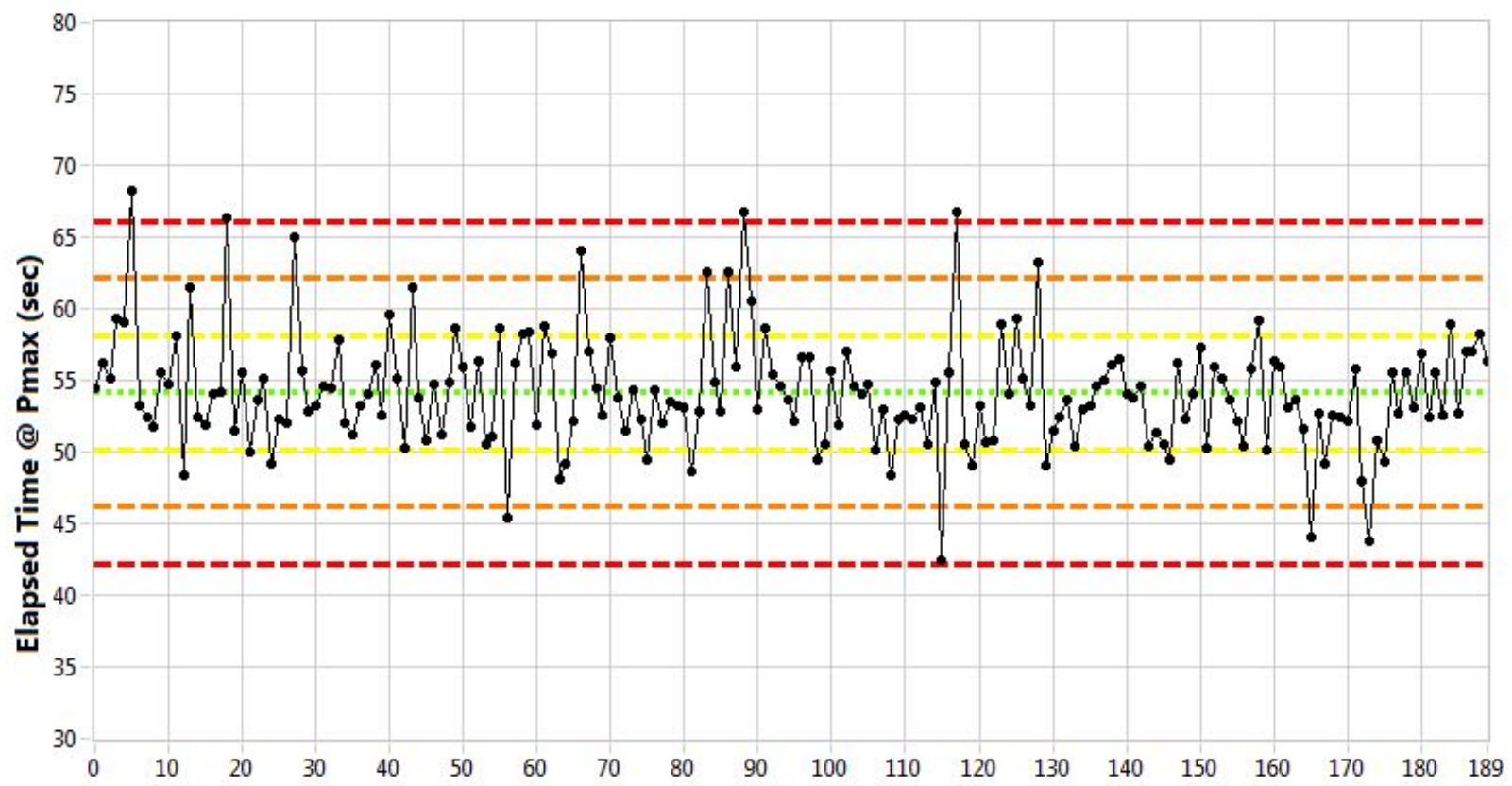

Figure B-1. Elapsed Time @ Max Load (sec), mean = 54.1, standard deviation = 3.98.

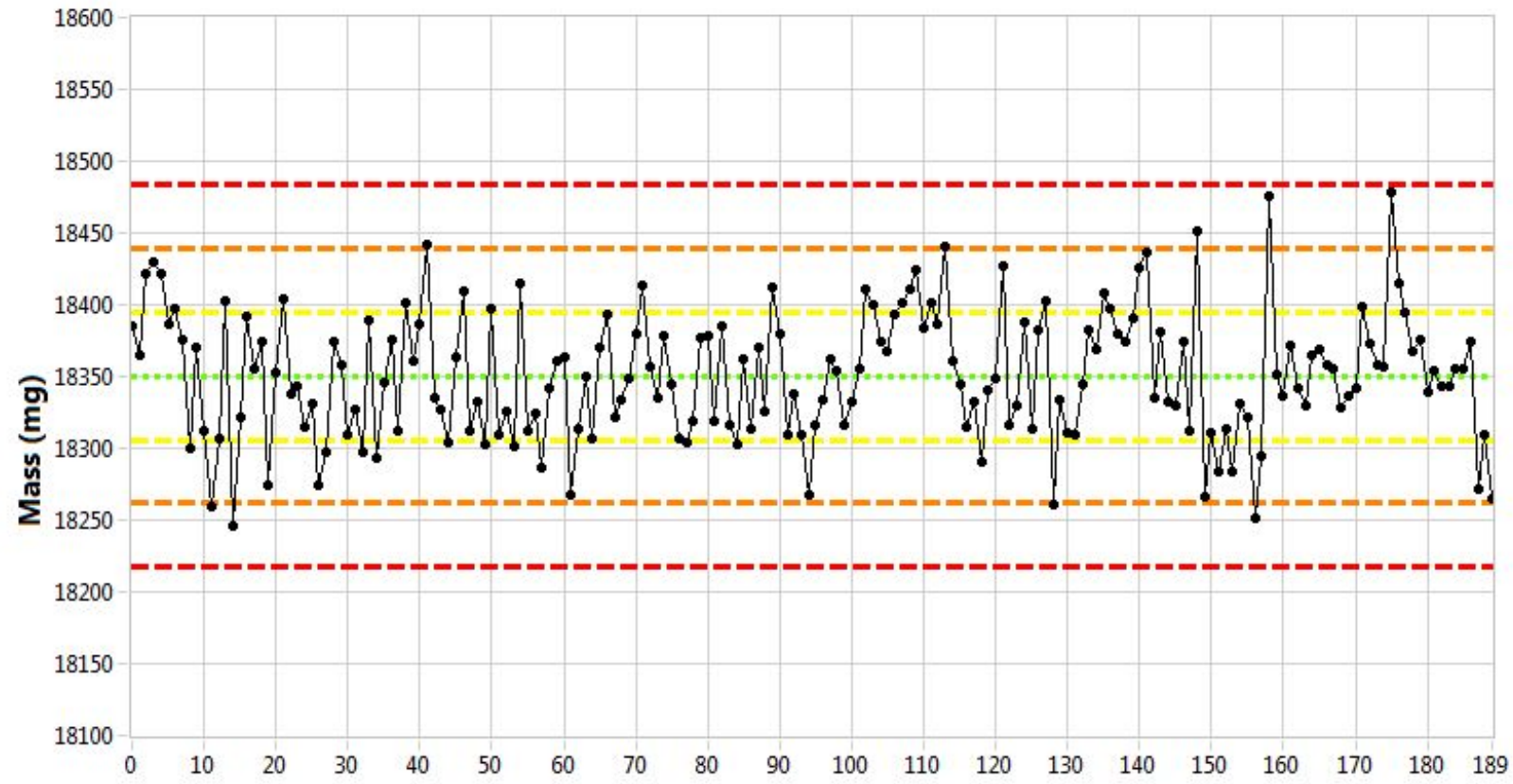

Figure B-2. Mass $(\mathrm{mg})$, mean $=18350.5$, standard deviation $=44.47$. 
TEM-10200-1

$03 / 01 / 2012$

ENGINEERING CALCULATIONS AND ANALYSIS

Page B2 of B2

Rev. 06

Title: $\quad$ Baseline Characterization Database Verification Report - 2114 Billet A20570

ECAR No.: 4322

Rev. No.: $0 \quad$ Project No.: 32138

Date: $12 / 02 / 2019$

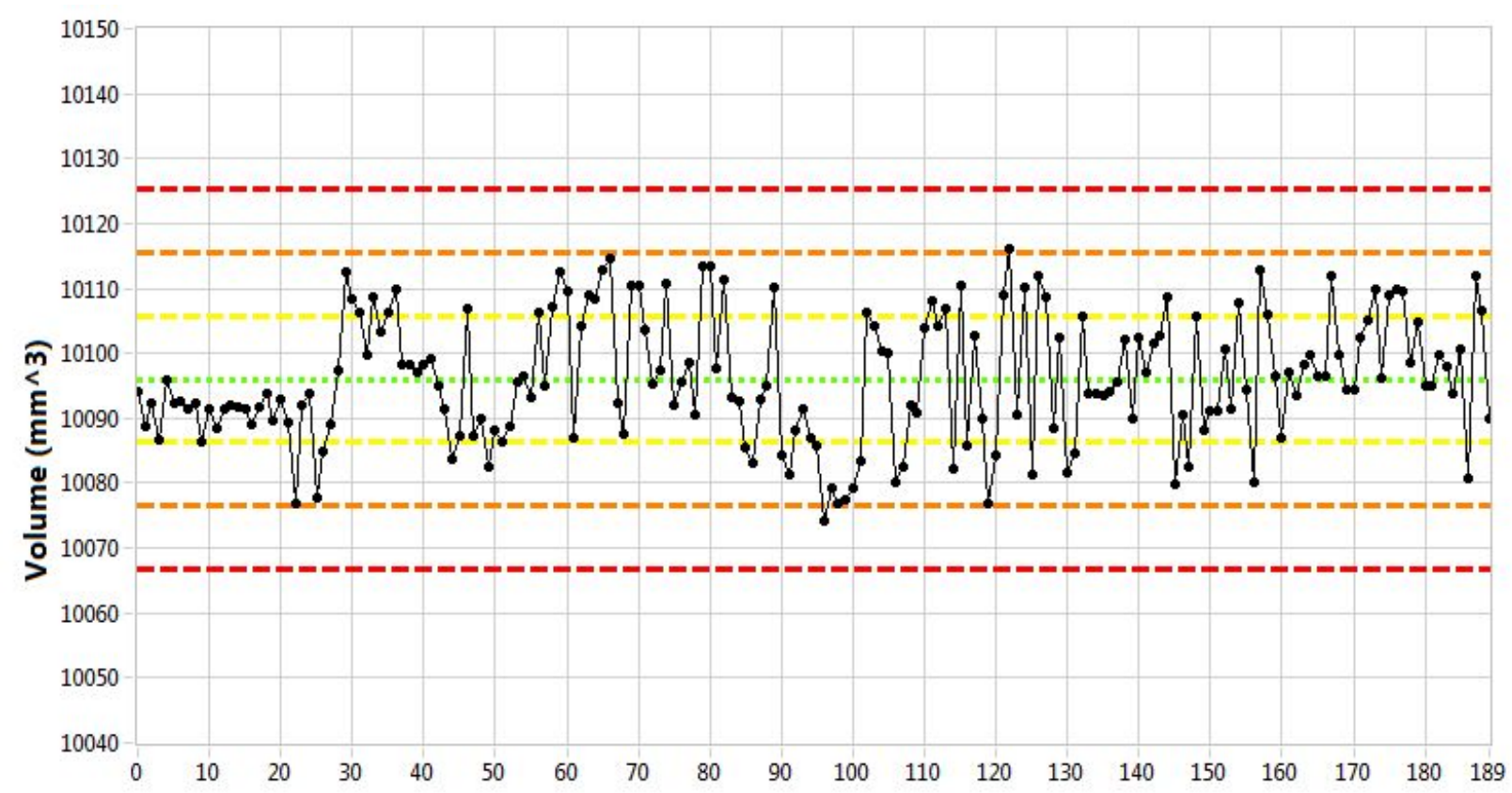

Figure B-3. Volume $\left(\mathrm{mm}^{\wedge} 3\right)$, mean $=10096.0$, standard deviation $=9.75$. 
TEM-10200-1

$03 / 01 / 2012$

ENGINEERING CALCULATIONS AND ANALYSIS

Page $\mathrm{C} 1$ of $\mathrm{C} 5$

Rev. 06

Title: $\quad$ Baseline Characterization Database Verification Report - 2114 Billet A20570

ECAR No.: 4322

Rev. No.: 0

Project No.: 32138

Date: $12 / 02 / 2019$

\section{Appendix C}

\section{Additional Tensile Specimen Database Plots (2114 A20570)}

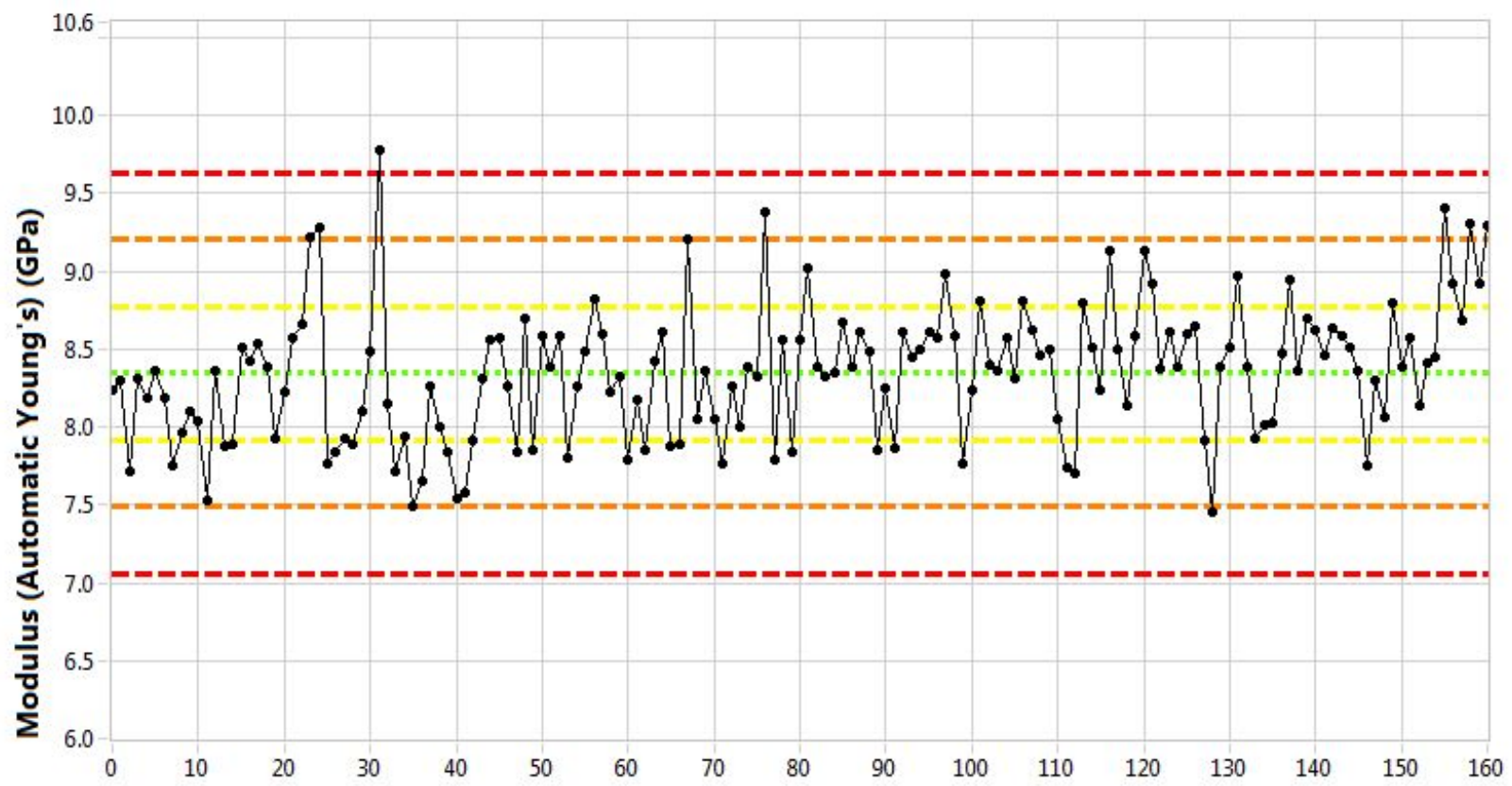

Figure C-1. Modulus (automatic Young's) $(\mathrm{GPa})$, mean $=8.3$, standard deviation $=0.43$.

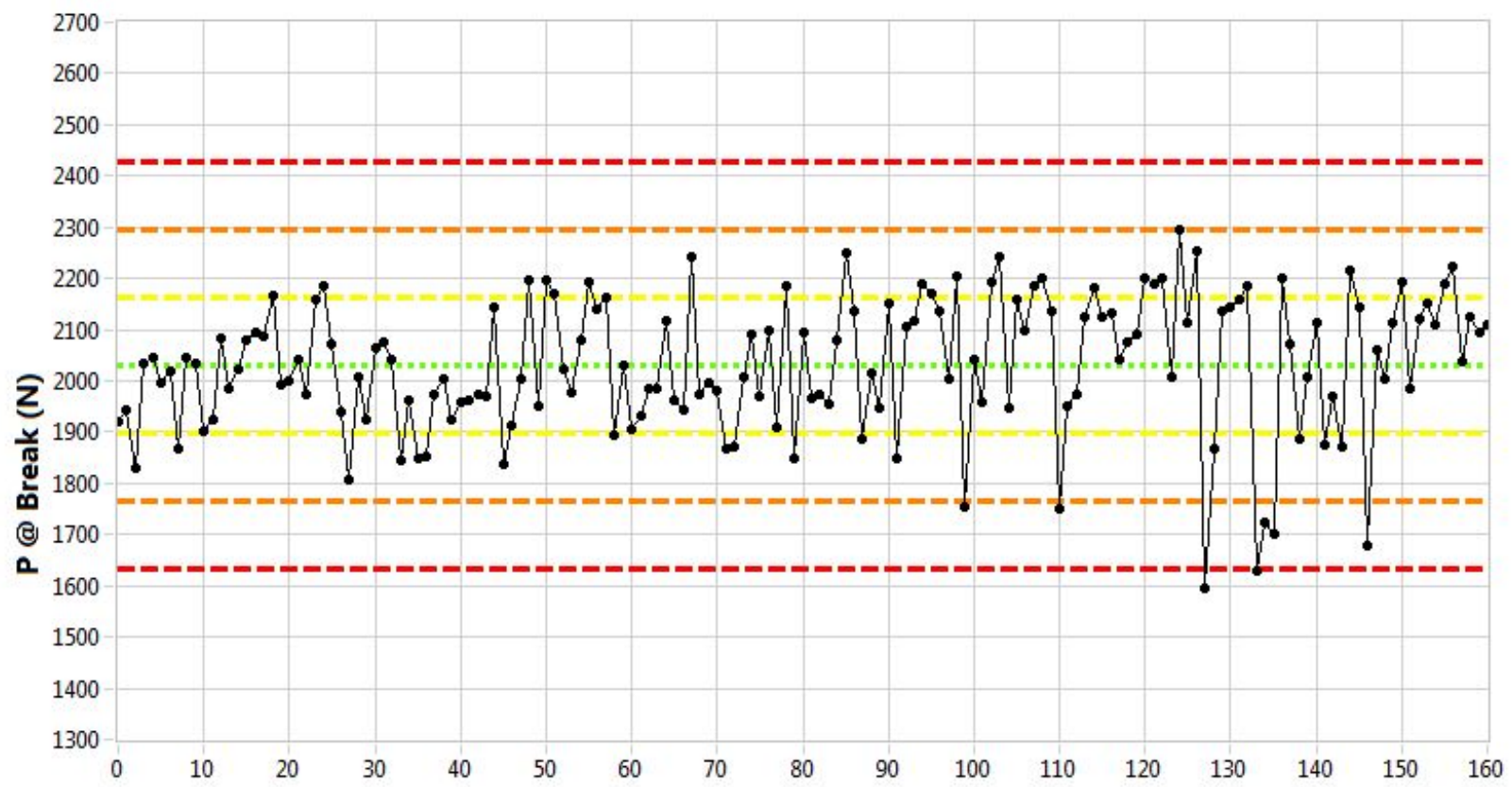

Figure C-2. Load at break $(\mathrm{N})$, mean $=2031.0$, standard deviation $=132.27$. 
TEM-10200-1

$03 / 01 / 2012$

ENGINEERING CALCULATIONS AND ANALYSIS

Page $\mathrm{C} 2$ of $\mathrm{C} 5$

Rev. 06

Title: $\quad$ Baseline Characterization Database Verification Report - 2114 Billet A20570

ECAR No.: 4322

Rev. No.: $0 \quad$ Project No.: 32138

Date: $12 / 02 / 2019$

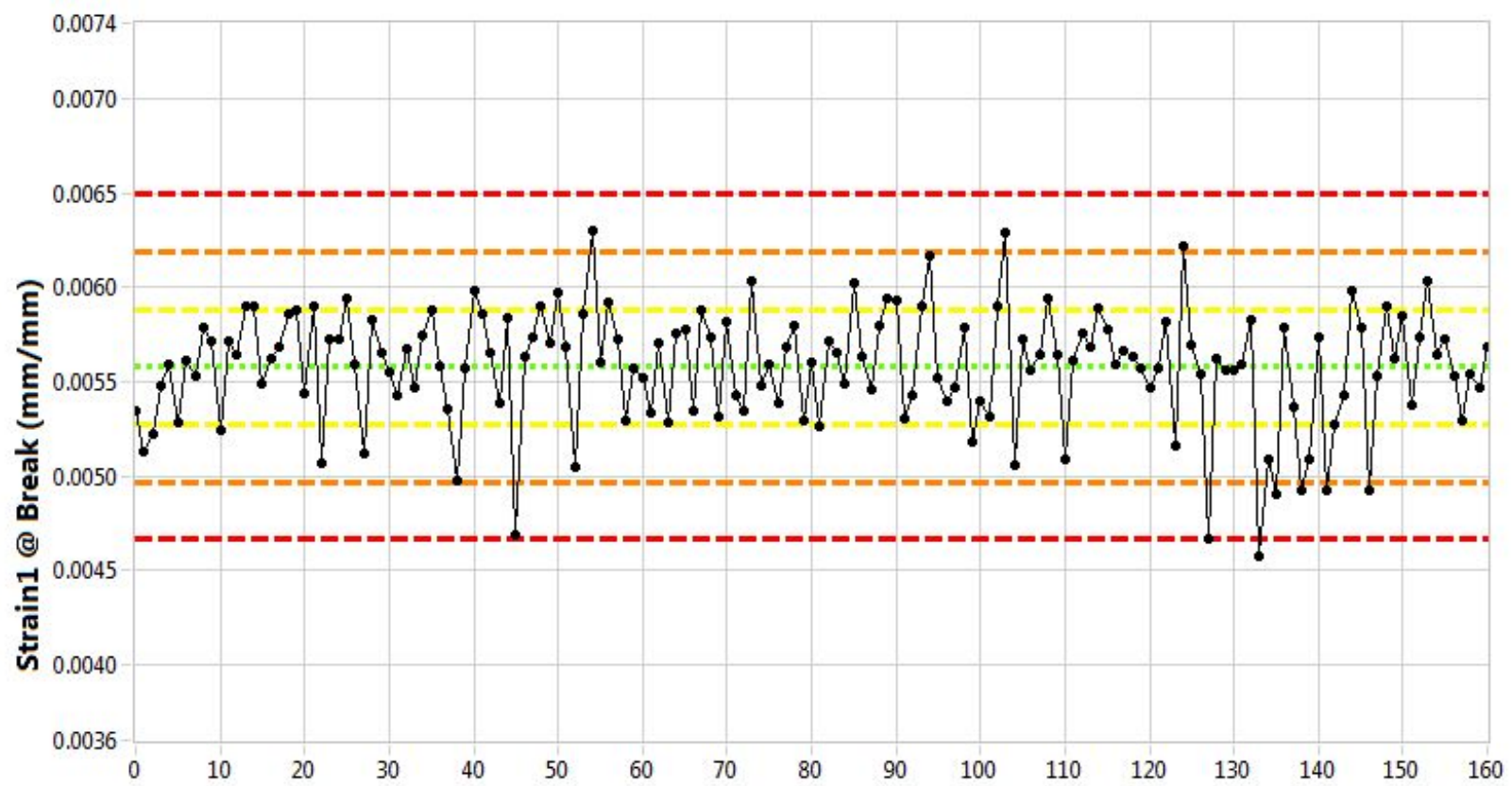

Figure C-3. Strain 1 at break $(\mathrm{mm} / \mathrm{mm})$, mean $=0.0056$, standard deviation $=0.0003$.

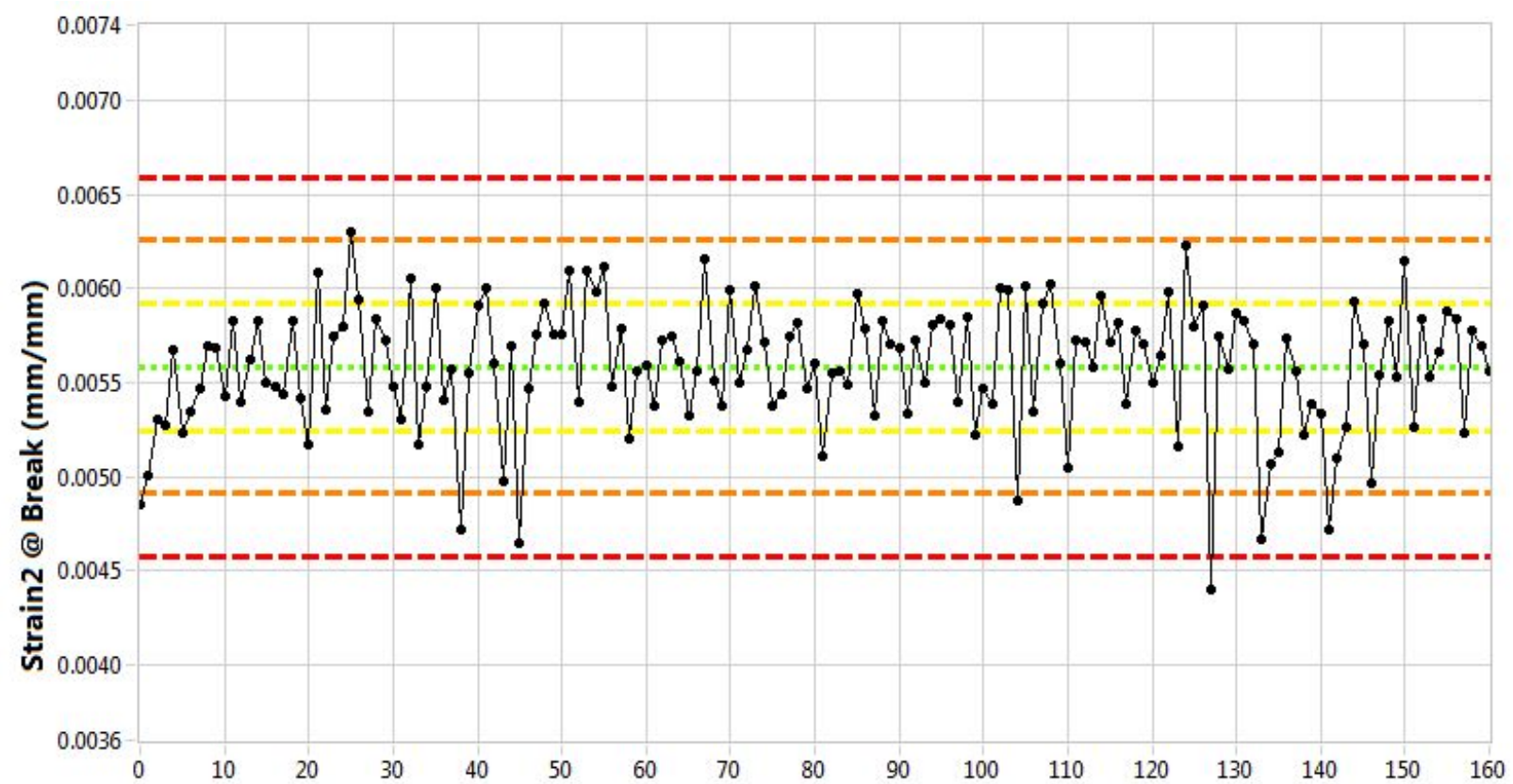

Figure C-4. Strain 2 at break $(\mathrm{mm} / \mathrm{mm})$, mean $=0.0056$, standard deviation $=0.0003$. 
TEM-10200-1

$03 / 01 / 2012$

ENGINEERING CALCULATIONS AND ANALYSIS

Page $\mathrm{C} 3$ of $\mathrm{C} 5$

Rev. 06

Title: $\quad$ Baseline Characterization Database Verification Report - 2114 Billet A20570

ECAR No.: 4322

Rev. No.: $0 \quad$ Project No.: 32138

Date: $12 / 02 / 2019$

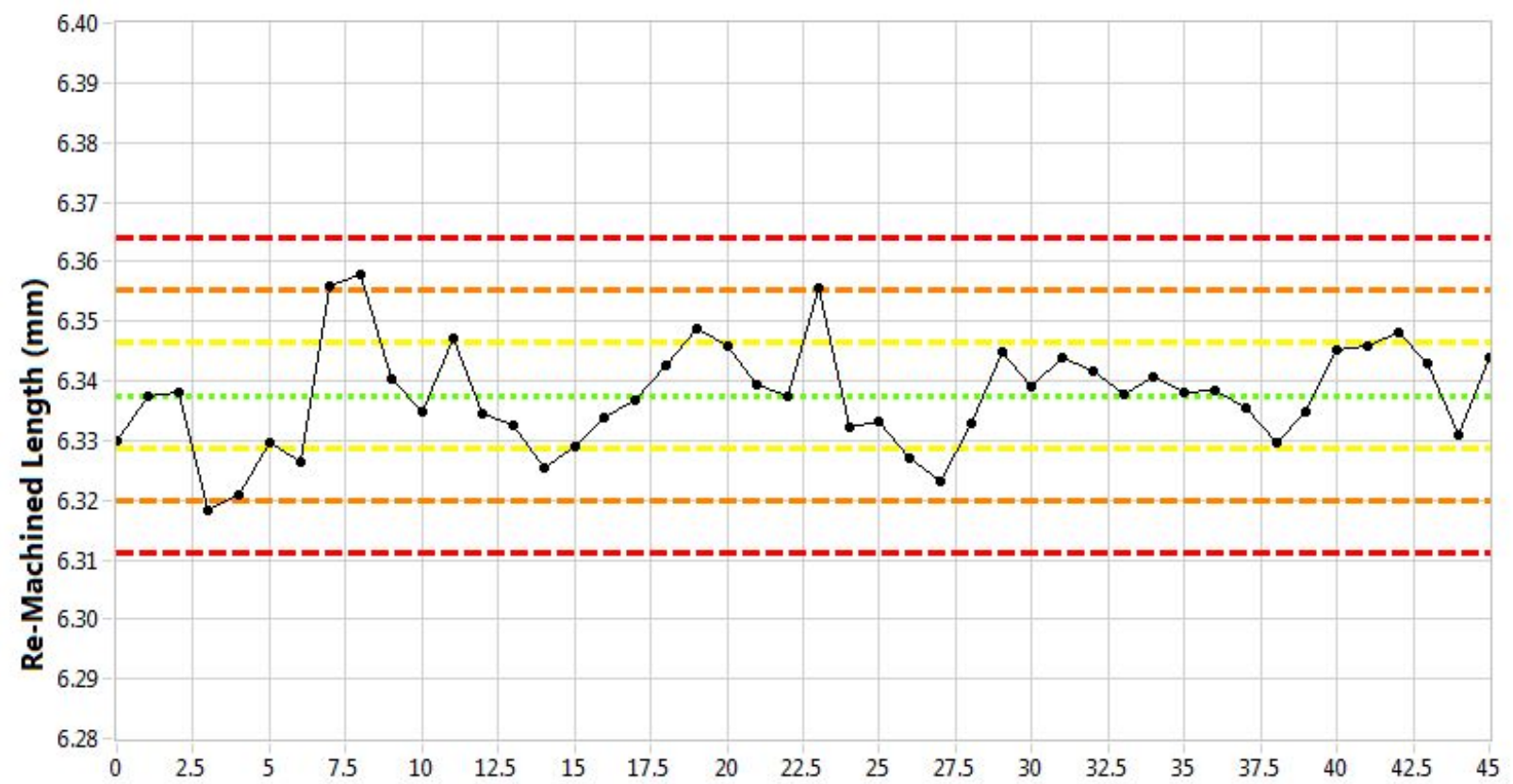

Figure C-5. Remachined Length $(\mathrm{mm})$, mean $=6.3375$, standard deviation $=0.0088$.

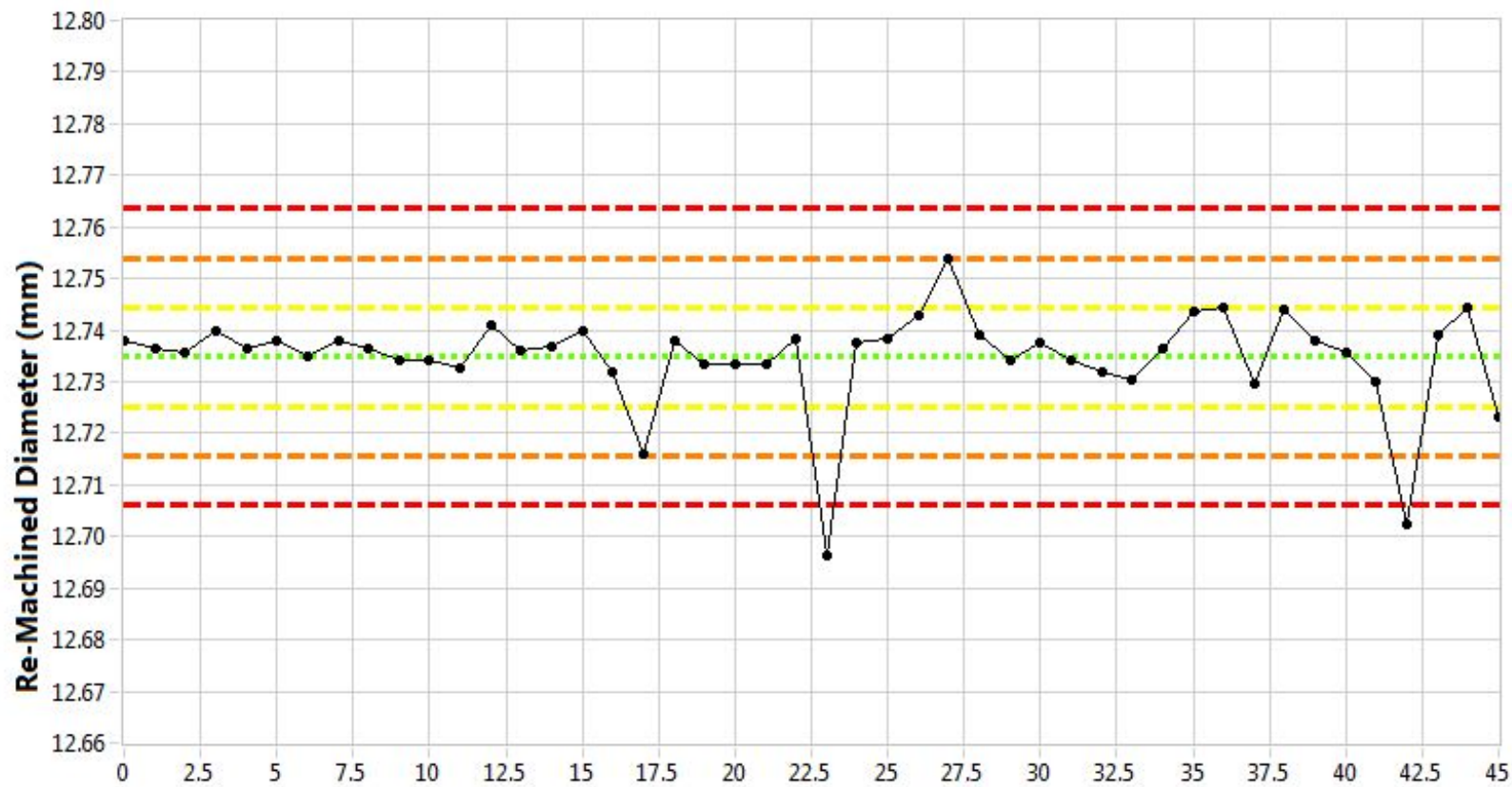

Figure C-6. Remachined Diameter $(\mathrm{mm})$, mean $=12.7348$, standard deviation $=0.0096$. 
TEM-10200-1

$03 / 01 / 2012$

ENGINEERING CALCULATIONS AND ANALYSIS

Page $\mathrm{C} 4$ of $\mathrm{C} 5$

Rev. 06

Title: $\quad$ Baseline Characterization Database Verification Report - 2114 Billet A20570

ECAR No.: 4322

Rev. No.: $0 \quad$ Project No.: 32138

Date: $12 / 02 / 2019$

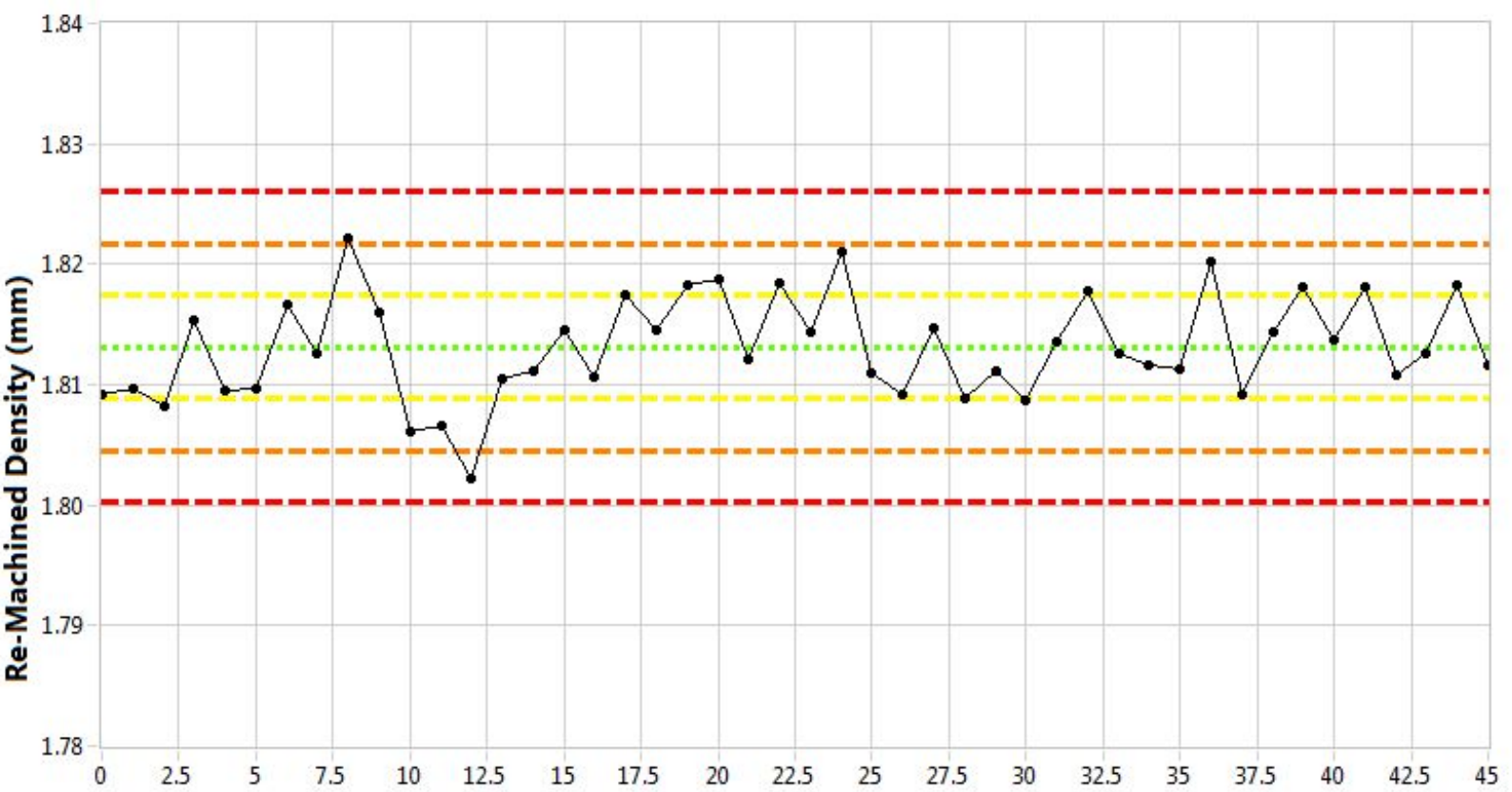

Figure C-7. Remachined Density $\left(\mathrm{g} / \mathrm{cm}^{\wedge} 3\right)$, mean $=1.8131$, standard deviation $=0.0043$.

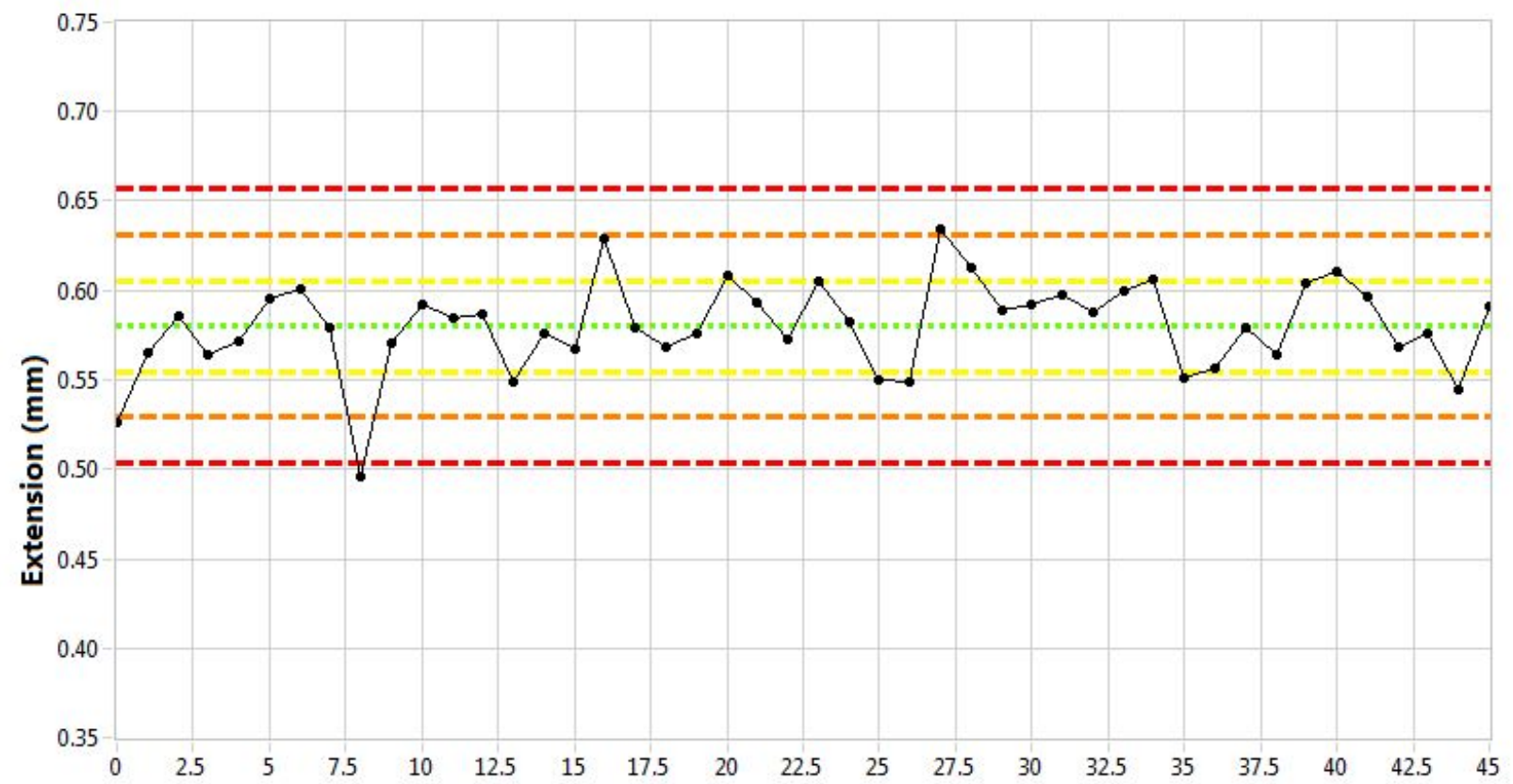

Figure C-8. Split disc extension $(\mathrm{mm})$, mean $=0.5801$, standard deviation $=0.0255$. 
TEM-10200-1

$03 / 01 / 2012$

ENGINEERING CALCULATIONS AND ANALYSIS

Page C5 of C5

Rev. 06

Title: $\quad$ Baseline Characterization Database Verification Report - 2114 Billet A20570

ECAR No.: 4322

Rev. No.: $0 \quad$ Project No.: 32138

Date: $12 / 02 / 2019$

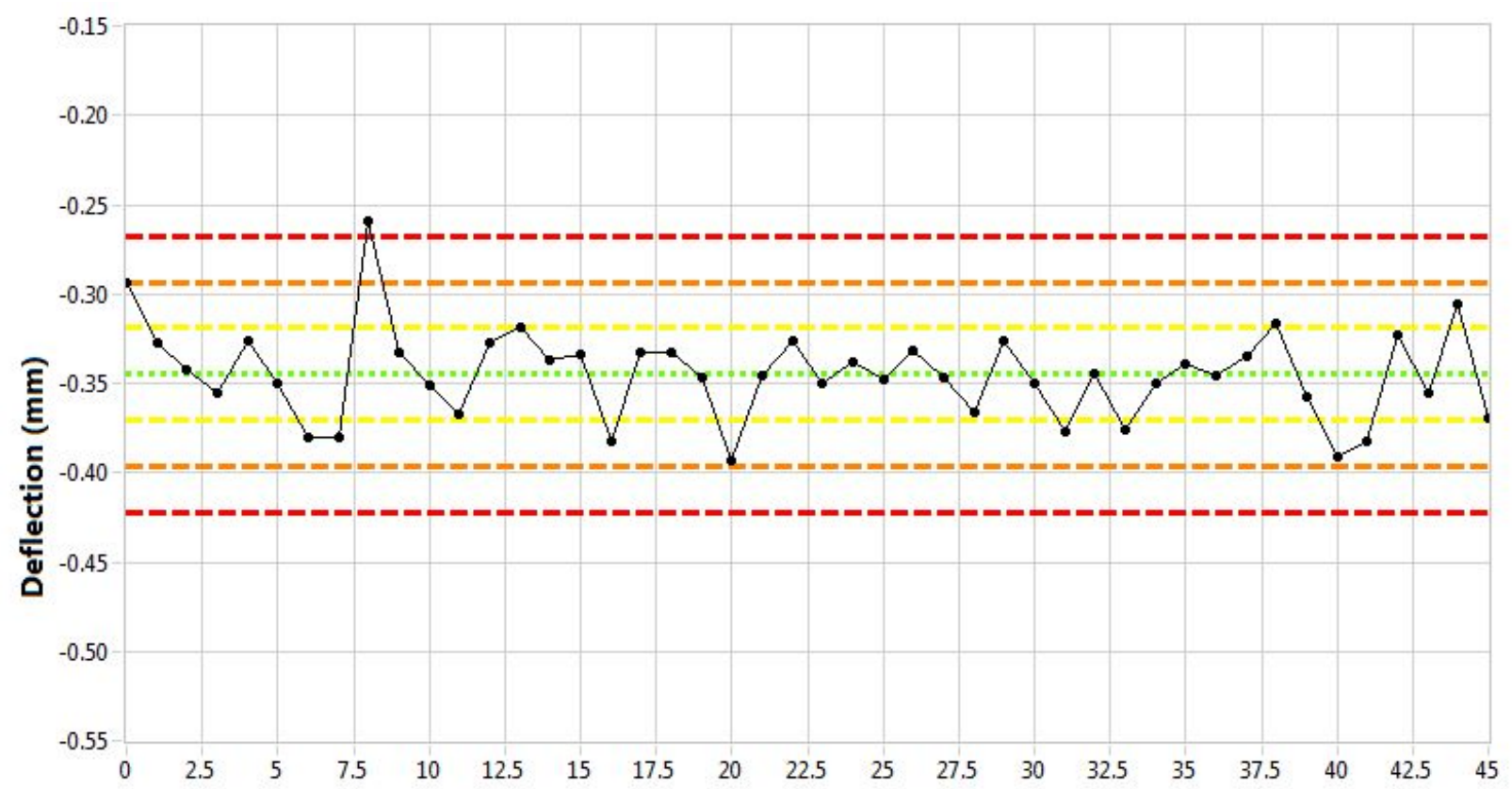

Figure C-9. Split disc deflection $(\mathrm{mm})$, mean $=-0.3450$, standard deviation $=0.0258$. 